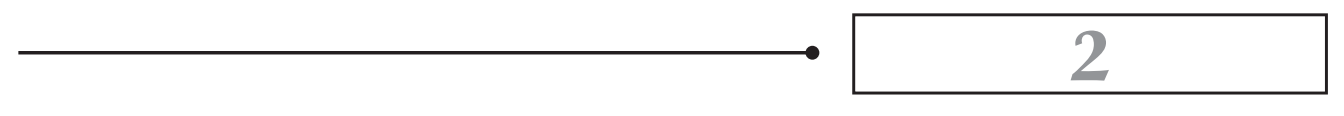

\title{
A INEXECUÇÃo DA DÍVIDA PÚBLICA
}

Se a dívida pública comporta a análise jurídica a partir das instituições que dela participam, as situações de inadimplemento são, em alguma extensão objeto de incidência normativa, ainda que, em alguns setores, o fenômeno jurídico seja pouco consistente. Identificar quais são os setores objeto de normatividade e, além disso, quase são as normas materiais ou procedimentos aplicáveis não chega a ser tarefa das mais esperançosas, a ponto de já se ter afirmado que esta é uma tarefa extremamente complexa, mas inútil em razão da fragilidade com que o direito se apresenta, quando se apresenta. ${ }^{115}$ As transações com instrumentos de endividamento público ocorrem em cenários nos quais a aplicação de categorias normativas tais como o lícito e o ilícito, bem como as regras de procedimento e distribuição de competências para a solução de conflitos, afeta os resultados esperados por cada uma das partes. Estas categorias jurídicas, no entanto, como parte de um cenário global fragmentado, assumem feições híbridas. Assim, os resultados das transações dependem da capacidade dos diversos atores de lidar com elementos normativos que não se prendem à tábua tradicional de distribuição das matérias jurídicas, mas que se situam ora entre atos jurídicos bilaterais e multilaterais, de direito público e privado, de direito internacional ou interno. ${ }^{116} \mathrm{~A}$ complexidade resultante retoma a

115 Cf. DOLZER, R. Staatliche Zahlungsunfähigkeit: zum Begriff und zu den Rechtsfolgen im Völkerrecht. In: JEKEWITZ, J. (Coord.). Des Menschen Recht zwischen Freiheit und Verantwortung. Berlim: Duncker und Humblot, 1989, p. 531.

116 FISCHER-LESCANO, A.; TEUBNER, G. Regime-Kollisionen: zur Fragmentierung des globalen Rechts. Frankfurt a.M.: Suhrkamp, 2006, p. 137. 
ideia de que o cenário global propõe desafios que surgem de vários contextos normativos específicos e simultâneos.

Este capítulo apresenta as formas de extinção da dívida pública e distingue aquelas que resultam do curso normal do cumprimento das obrigações de outras que configuram casos de inadimplemento. $\mathrm{O}$ tema da reestruturação da dívida pública será adequadamente delimitado para que se distingam seus tipos mais relevantes, entendendo-se que, a despeito de certa ficção de que o direito não se ocupa de revisões das obrigações do Estado porque sua capacidade de pagamento não se extingue, é possível não apenas identificar características jurídicas, mas também apontar a diversidade das fontes de normatividade da regulação das formas de inexecução da dívida pública.

\subsection{A FREQUÊNCIA DAS CRISES}

O poder financeiro do Estado é muitas vezes confundido, em algumas de suas características, com a base material sobre a qual é exercido. A permanência dos meios disponíveis ao exercício da atividade financeira, que ressoa a canônica descrição da soberania como um poder absoluto e perpétuo, ${ }^{117}$ pode ser erroneamente equiparada à inesgotabilidade dos meios de que dispõe o Estado. Se, por um lado, o poder de tributar não se exaure com a efetiva arrecadação dos tributos, ou se o poder monetário prossegue ainda além da colocação de papel-moeda em poder do público, isto não quer dizer que os recursos designados como públicos sejam da mesma forma perenes. A capacidade de pagamento do Estado, no entanto, é assumida como um dos traços mais elementares das finanças públicas, ou um verdadeiro dogma, ${ }^{118}$ cuja plausibilidade inspira legislaçóes jurídico-financeiras a não considerar como indispensável o condicionamento das despesas públicas ao volume das receitas. A despeito de políticas supranacionais procurarem, com mais ou menos eficácia, conter o "viés deficitário" dos orçamentos públicos, ou a continuidade de políticas financeiras insustentáveis, por meio de instrumentos como o planejamento plurianual, ${ }^{119}$ a incapacidade de pagamento do Estado é vista com algum

117 "La souveraineté est la puissance absolue et perpétuelle d'une République” BODIN, J. Le Six Libres de la République. Paris: Librairie Générale Française, 1993 (1583), p. 74.

118 É assim que K. v. LEWINSKI refere-se à crença na ilimitada capacidade de pagamento do Estado (cf.Öffentlichrechtliche Insolvenz und Staatsbankrott. Tübingen: Mohr Siebeck, 2011, p. 4).

119 Sobre a governança fiscal da União Europeia e as diretrizes para políticas orçamentárias sustentáveis, ver HALLERBERG, M.; STRAUCH, R.; von HAGEN, J. The Design of Fiscal Rules and Forms of Governance in European Union Countries. Governance and the Efficiency of Economic Systems Discussion Paper n. 150, Mannheim, jun. 2006. 
ceticismo - senão como algo impossível, ao menos como um evento improvável. Mesmo nas perspectivas mais moderadas, fala-se não em imunidade à insolvência (bankruptcy proofness), mas na sua ocorrência remota (bankruptcy remoteness). ${ }^{120}$

Algumas técnicas de emissão da dívida pública mostram, ainda, que não é de todo incomum o recurso à dívida perpétua, em que não há prazo de maturidade fixado e, em consequência, o adimplemento não se dá pelo reembolso do capital emprestado, mas pelo pagamento de juros ou rendas por longuíssimo período. De um lado, a promessa de pagamento apenas de juros, mas a escusa de devolução do principal, apenas soa possível se o devedor é dotado de características bastante peculiares. ${ }^{121}$ A dívida perpétua representa, com sua configuração inusual, a particularidade da confiança de que goza o Estado. Se ela aponta, de um lado, que o devedor poderá não pagar a totalidade do capital emprestado, ainda assim empréstimos são concedidos com a previsão de que retorno se dará sob apenas pela incidência de determinadas taxas de interesse sobre o capital. ${ }^{122} \mathrm{O}$ crédito público, portanto, pode ainda ser suficiente para a participação ativa nos mercados mesmo diante de perspectivas desfavoráveis de cumprimento dos compromissos, confiança que nem sempre pode ser cogitada para devedores privados.

Estas peculiares características do crédito público são adequadamente explicadas pelo poder financeiro de que dispõe o Estado. Mas não apenas no âmbito do direito financeiro se poderia identificar, em caráter subjacente a diversas de suas normas, o reconhecimento de que os déficits públicos apresentam finalidades específicas em determinadas quadras conjunturais que não comprometem, se responsavelmente empregados, a solvabilidade de um país. A regulação internacional do setor bancário sistemicamente relevante atribui um risco consideravelmente menor aos investimentos em papeis soberanos mais confiáveis, conforme assim determinem as agências de classificação de risco. Estas medidas impactam os requerimentos de capital das instituições financeiras, menores para investimentos de menor risco. No âmbito do Banco de Compensações Internacionais (BIS), os acordos de Basileia II e III aperfeiçoaram o corte mais linear entre o risco-país de membros e não membros da OCDE, que havia sido anteriormente estabelecido pelo acordo de

${ }^{120}$ LEWINSKI, K. v. Öffentlichrechtliche Insolvenz und Staatsbankrott. Tübingen: Mohr Siebeck, 2011, p. 2.

121 JARACH, Dino. Finanzas Publicas y Derecho Tributario. ed. Buenos Aires: Editorial Cangallo, 1993, p. 886.

122 A emissão da dívida perpétua se apresentou mais recentemente, por exemplo, como alternativa de financiamento da Grécia. Cf. SPIEGEL, P. Leaked: Greece's New Debt Restructured Plans. Financial Times, 5 de jun. de 2015. 
Basileia I para a relação entre as exigências de capital mínimo e o risco do investimento (então considerado nulo para os países-membros). ${ }^{123}$ Este quadro regulatório considera a capacidade de pagamento do Estado como um pressuposto ao qual as situações de crise são descritas como eventos excepcionais.

E, no entanto, os Estados não poucas vezes deixam de pagar a dívida pública, seja porque não reúnem os meios disponíveis para isso no prazo previsto, seja porque não o desejam fazer. As políticas de que se dispõe mostram ter certos limites, tais como uma carga tributária já excessivamente elevada, os efeitos inflacionários da política monetária e a escassez do patrimônio público alienável para a satisfação dos credores. Diante destes contextos de saturação, a suspensão dos pagamentos da dívida pode se mostrar como uma alternativa mais viável do que o aumento politicamente intolerável de uma tributação já excessiva, medidas inflacionárias ou a alienação de bens públicos, que poderiam chegar ao extremo de uma cessão de parte do território que dificilmente um Estado empreenderia voluntariamente. ${ }^{124}$ Os limites do poder financeiro se mostraram também universais com as recentes crises financeiras globais desencadeadas após o ano de 2008. Não apenas os países em desenvolvimento enfrentaram crises de pagamento, com as habituais acusações de corrupção e má gestão, mas também as naçōes desenvolvidas viram sua capacidade financeira sob risco. Nas décadas mais recentes, após as crises latino-americanas dos 80, russa e asiática dos 90 e argentina do começo do século, o significativo endividamento do setor público e privado de países industriais, não raro com a absorção da dívida de setores bancários em crise pelos orçamentos públicos nacionais, retomaram o debate global sobre a solvência do Estado. ${ }^{125}$ As crises podem ter causas variadas, desde aquelas puramente financeiras ou relacionadas a choques na economia real até eventos de natureza política e militar. Em qualquer delas, os níveis excessivos da dívida pública combinados com a instabilidade dos fluxos de capitais gerariam situações dramáticas de crise.

123 STEPHANOU, C.; MENDOZA, J. C. Credit Risk Measurement under Basel II: an Overview and Implementation Issues for Developing Countries. World Bank Policy Research Working Paper n. 3556, Washington, D.C., 2005, p. 3-4. Para conferir os métodos de mensuração de risco, v. HANNOUN, H. Sovereign Risk in Bank Regulation and Supervision. Bank for International Settlements, Basileia, 2011, p. 12; e KASSOW, Achim. The Interaction Between Sovereign Debt and Risk Weighting under the Capital Requirements Directive (CRD) as an Incentive to Limit Government Exposures. European Parliament, Bruxelas, 2010, p. 5.

124 BORCHARD, P. State Insolvency and Foreign Bondholders. Washington, D.C.: Beard Books, 1951, vol. 1, p. 118.

125 WAIBEL, M. Staateninsolvenzen in Historischer Sicht. In: KODEK, G.; REINISCH, A. (Coord.). Staateninsolvenz. Viena: Bank Verlag, 2012, p. 56. 
Alguma informação histórica pode mostrar que a solvência do Estado é uma presunção relativa. Um preocupado David Hume alertava contra o endividamento irresponsável, que tenderia ao abuso ante a possibilidade que confere ao governante de fazer uma grande figura de sua administração a despeito das consequências de longo prazo. ${ }^{126} \mathrm{O}$ uso e o abuso da dívida pública marcavam uma época em que ela fora para o Estado um agente mais poderoso do que a pólvora. ${ }^{127}$ Ao escrever sobre a bancarrota de Estados, um importante autor alemão do início das primeiras décadas do século XX havia descrito o centênio anterior como uma sucessão de moratórias e cancelamentos dos pagamentos do Estado, fossem na Europa, na África ou na América Latina. Estima-se que a França tenha declarado moratória ao menos uma vez a cada geração, mas diversos outros países a apresentaram com elevada frequência. No império alemão, diversos de seus estados, tais como a Prússia (1807 e 1813), Vestfália (1812), Kurhessen (1814) e Schleswig-Holstein (1850). Ainda no continente europeu, Áustria (1802, 1805/1806, 1811, 1816 e 1868), Holanda (1814), Espanha (1820, 1831, 1834, 1851, 1867, 1872 e 1882), Portugal (1837, 1852 e 1892), Rússia (1839), Turquia (1875, 1876 e 1881) e, para pouco surpreender a um contemporâneo, a Grécia (1826 e 1893). Na África, a crise financeira do Egito, de 1876. E, na América, os abundantes exemplos da sequência de moratórias de doze estados-membros dos Estados Unidos após a Guerra de Secessão e praticamente todos os países sul-americanos. O final do século XIX se transformaria na era da débâcle financeira dos governos, diria Politis. ${ }^{128}$

Os credores não seriam imediatamente aliviados nos anos seguintes. Já nas primeiras décadas do século XX, dos 61 Estados estrangeiros (incluindo entes subnacionais) que colocaram títulos em negociação na bolsa de Londres, apenas pouco mais da metade (um total de 35) era considerada confiável, porque em cumprimento de suas obrigações financeiras (aí incluídos os estados de Alagoas, Rio de

${ }^{126}$ Essays, Moral, Political and Literary. Indianapolis: Liberty Fund, 1987 (1889), p. 350. “It is very tempting to a minister to employ such an expedient, as enables him to make a great figure during his administration, without overburthening the people with taxes, or exciting any immediate clamours against himself. The practice, therefore, of contracting debt will almost infallibly be abused, in every government. It would scarcely be more imprudent to give a prodigal son a credit in every banker's shop in London, than to empower a statesman to draw bills, in this manner, upon posterity."

127 O comentário é de Jean-Baptiste Say, em A Treatise on Political Economy. Filadélfia: Claxton, Remsen \& Hattelfinger 1821, p. 480. "The faculty of borrowing is a more powerful agent, than even gun-powder; but probably the gross abuse that is made of it, will soon destroy its efficacy."

${ }^{128}$ Les Emprunts d'État en Droit International. Paris: Durand et Pedone-Lauriel, 1894, p. 1. 
Janeiro e São Paulo), 11 com atendimento parcial dos compromissos (entre eles os estados da Bahia e Pará e o próprio Brasil) e 15 com interrupção total (nenhum ente brasileiro, porém todos, com exceção de Montenegro, pertencentes ao continente americano). ${ }^{129}$ A Revolução Russa de 1917 teria por resultado a instalação de um novo regime que repudiaria toda a dívida do período czarista, e esta experiência demonstra como os processos de renegociação podem ser longos. Os conflitos com os credores franceses seriam resolvidos apenas após o fim da União Soviética, por um acordo franco-russo de 1997 sobre o cancelamento de dívidas recíprocas anteriores a $1945 .{ }^{130}$ Credores públicos e privados foram afetados pelas consequências financeiras das duas guerras mundiais, um período em que o alto endividamento e as soluções tentadas deixariam consequências graves. As reparações de guerra impostas à Alemanha pelo Tratado de Versalhes, avaliadas por Keynes como muito além de sua capacidade financeira e cujas provisões irreais representariam um perigo para o futuro, impuseram ao país elevados níveis de uma dívida que seria administrada pela hiperinflação. ${ }^{131} \mathrm{O}$ alto estoque de débitos dos Estados nacionais após o final da segunda guerra teria ainda que ser resolvido por subsequentes tratativas, após a ocorrência de numerosas interrupções dos pagamentos. $\mathrm{O}$ acordo de Londres sobre a dívida alemã, de 1953, se preocupou em reduzir o nível de endividamento daquele país como condição para a reconstrução de sua economia, levando em conta as perspectivas futuras e a real capacidade de pagamento. ${ }^{132}$ Os regimes comunistas instalados na China (1949), na Tchecoslováquia (1952) e em Cuba (1960), por sua vez, também cancelariam os pagamentos das dívidas anteriores. ${ }^{133}$

Os anos de 1970 veriam ainda alteraçóes na qualidade e na quantidade do financiamento externo do Estado. O crédito privado ganhou importância cada vez

129 O ano de referência é o de 1916. Um relato abrangente das crises de endividamento do século XIX e início do século XX pode ser lido em MANES, A. Staatsbankrotte: Wirtschaftliche und Rechtliche Betrachtungen. 2. ed. Berlim: Karl Siegismund, 1919, p. 15 e seguintes. Para experiências anteriores, que retomam as inúmeras declarações de moratoria de Estados desde o século XVI, v. WAIBEL, M. Staateninsolvenzen in Historischer Sicht. In: KODEK, G.; REINISCH, A. (Coord.). Staateninsolvenz. Viena: Bank Verlag, 2012.

130 SZUREK, S. Épilogue d'un Contentieux Historique. Annuaire Français de Droit International, Paris, n. 44, 1998, p. 144-66.

131 The Economic Consequences of the Peace. Nova Iorque: Harcourt, Brace and Howe, 1920, p. 92 .

132 DELAUME, G. Legal Aspects of International Lending and Economic Development Financing. Nova Iorque: Oceana, 1967, p. 53.

133 STURZENEGGER, F.; ZETTELMEYER, J. Debt Defaults and Lessons from a Decade of Crises. Cambridge: the MIT Press, 2006, p. 4. 
maior, com o crescimento dos canais de transmissão de capitais pela via dos bancos comerciais. A dívida sindicada tornou-se parte da agenda de desenvolvimento de muitos países, em razão, principalmente, do aumento da disponibilidade de recursos e das baixas taxas de juros. Estados latino-americanos passariam a se valer dessas fontes. A reversão das tendências internacionais favoráveis nos anos seguintes provocaria a generalizada crise da dívida latino-americana, ${ }^{134} \mathrm{em}$ continuação a uma longa experiência de moratórias vinda de décadas anteriores. Sobre os casos pretéritos, bastaria lembrar que a fundação do Clube de Paris se deveu à necessidade de formular um acordo entre a Argentina em moratória e Estados europeus credores, em 1956. ${ }^{135}$

Ainda que a dívida pública e os instrumentos jurídicos da suspensão dos pagamentos e eventual reestruturação tenham características variáveis ao longo dos períodos narrados, o que estes casos demonstram é que não deve passar como uma anormalidade que a capacidade de pagamento do Estado se esgote, ainda que temporariamente. Entre as crises recentes, podem-se destacar o superlativo exemplo argentino, a partir de 2001, e as idas e vindas dos países-membros da União Europeia em torno das negociações com os credores, sob a constante ameaça de moratórias de efeitos imprevisíveis. A diversificação dos instrumentos de endividamento acrescenta outros níveis de complexidade à configuração atual do problema. A dívida contratual entre Estados, que se associava aos critérios estratégicos de relacionamento, tem cedido importância para os vínculos predominantemente econômicos entre o Estado e agentes privados, notadamente aqueles que negociam títulos públicos em mercados abertos. A multiplicação dos credores, não poucas vezes de identidade desconhecida pelo receptor do crédito, potencializa a instabilidade das relações em razão da maior dificuldade de coordenação de interesses. A tese de que este é um tema sem qualquer consequência jurídica, como se concluiria da Doutrina Drago e da caracterização da dívida pública como uma mera dívida de honra, é insustentável. A diversificação do cenário jurídico exibe, no entanto, um aparente paradoxo: ao mesmo tempo em que se notam fragmentos de regimes normativos aplicáveis (o que poderia dar a impressão imprecisa de um excesso de normatividade), as lacunas evidenciam um amplo espaço de formulação que estimula propostas de organização dos mecanismos ordenados de resolução das crises.

${ }^{134}$ DEVLIN, R.; FRENCH-DAVIS, R. The Great Latin America Debt Crisis. Revista de Economia Política, v. 15, n. 3, jul.-set. 1995.

135 Cf. SOURROUILLE, J. V. Activos y Pasivos Externos de la Argentina desde Fines de la Segunda Guerra Mundial hasta 1958. Desarrollo Económico, vol. 47, n. 185, abr.-jun. 2007, p. $25-71$. 


\subsection{A IMPRECISÃO CONCEITUAL: BANCARROTA, INSOLVÊNCIA, DEFAULT}

A ideia de crise financeira do Estado traduz um conjunto de fenômenos diversos, o que se reflete na imprecisão dos conceitos usualmente aplicados para caracterizá-la. Termos de múltipla significação são utilizados em paralelismo a categorias de ramos jurídicos cuja primeira preocupação não é a situação financeira do Estado, ou ainda em desconsideração a elementos propriamente normativos com a excessiva remissão ao vocabulário econômico. Termos desse tipo são capazes de descrever situaçoos de fato, mas não são unívocos e tampouco têm sentido jurídico preciso. Fala-se em bancarrota, insolvência ou default para referir realidades diferenciadas que guardam diferenças quanto à conformação jurídica. Apesar de todos se referirem à manifestação de determinados momentos críticos nas finanças públicas, sua frequente utilização não significa um grau elevado de precisão conceitual, ainda que descrevam determinados fenômenos. Todos estes termos são capazes, no entanto, de ir além de seu sentido descritivo. Os mercados financeiros lidam com expectativas, e a sua simples pronúncia por uma voz autorizada (um representante do governo ou agências de avaliação de risco) poderia produzir o resultado que o enunciado pretendia significar. A menção séria à insolvência do Estado poderia rendê-lo insolvente na medida em que induzisse os diversos atores a tratá-lo como tal. As palavras não apenas descrevem realidades, mas são também capazes de produzi-las.

Daí as dificuldades terminológicas do tema. Não é apenas tecnicamente delicada a transposição intersistêmica de categorias conceituais ou o emprego de termos cujo sentido comum aponta para realidades jurídicas muito variadas; há um aspecto pragmático a ser considerado. A carga valorativa que se foi acumulando é capaz de tornar o uso de determinadas palavras de tal sorte inconveniente que os debates mais propositivos sobre cenários alternativos de configuração da arquitetura internacional da resolução de crises de dívida pública poderiam ser bloqueadas por questôes de terminologia.

Tome-se como primeiro caso a palavra de sentido mais drástico. Bancarrota, que vem do italiano banca rotta (banco quebrado), possuía uma conotação bastante concreta antes que fosse tomada pelo sentido metafórico de falência de uma instituição financeira. Os bancos de madeira em que se negociavam as trocas de moeda durante a Renascença eram quebrados (no sentido literal) caso aqueles que os operassem não pudessem efetuar as trocas combinadas. ${ }^{136} \mathrm{Com}$ isto, a bancarrota não

136 LEWINSKI, K. v. Öffentlichrechtliche Insolvenz und Staatsbankrott. Tübingen: Mohr Siebeck, 2011, p. 16-7. 
significava apenas o esgotamento financeiro, temporário ou permanente, de uma pessoa, mas a sua estigmatização, construída pelo humilhante rito público de destruição de suas instalações comerciais. A mancha da bancarrota não seria completamente afastada das instituições jurídicas, que ainda a preservariam como uma espécie de sanção ao devedor incapaz de pagar. Uma notável exceção é o direito falimentar norte-americano, para o qual a necessidade de retomar as funções econômicas do patrimônio paralisado do insolvente conduziria a uma abordagem mais pragmática e menos gravosa sobre a continuidade de suas atividades. Esta orientação difere, no entanto, daquela que se encontra em outras ordens jurídicas. É sintomático que o termo bancarrota apareça explicitamente, no direito alemão, apenas no Código Penal. ${ }^{137}$

Quando aplicada a qualquer forma de esgotamento ou impossibilidade de disposição dos meios de pagamento do Estado, esta marca negativa da palavra dissemina algumas resistências ao seu emprego, ainda que isso não impeça seu uso mais ou menos intensivo na literatura jurídica. Em trabalhos doutrinários alemães, a frequência do uso consagrou a bancarrota estatal como uma expressão de sentido corrente, definida por Manes como a "situação de não cumprimento das obrigações financeiras de um Estado". ${ }^{138}$ Algum deslocamento histórico e geográfico, porém, retomaria sua dimensão pejorativa. $\mathrm{Na}$ França, a menção à bancarrota do Estado fora à época revolucionária proibida em lei, pois aquela que Mirabeau chamaria de mot infâme era desonrosa à fé pública. ${ }^{139}$ Não menos radical é a opinião de um jurista holandês que, muito mais tarde, compararia os efeitos da bancarrota sobre a população civil em tempos de paz aos da lei marcial em tempos de guerra, com um agravante: a guerra poderia ser justa, a bancarrota jamais. ${ }^{140}$ A declaração

\footnotetext{
$\$ \$ 283$ e 283 a StGB.
}

138 Staatsbankrotte: Wirtschaftliche und Rechtliche Betrachtungen. 2. ed. Berlim: Verlag Von Karl Siegismund, 1919, p. 22. Ver, além disso, as seguintes obras já citadas: HUGO, G. Lehrbuch des Naturrechts. 4. ed. Berlim: August Mylius, 1819; LABAND, P. Das Staatsrecht des Deutschen Reiches. Friburgo: J. C. B. Mohr, 1891, vol. 4; FREUND, G. Die Rechtsverhältnisse der Öffentlichen Anleihen. Berlim: J. Guttentag, 1907. Mais recentemente, ver o amplo trabalho de LEWINSKI, K. v. Öffentlichrechtliche Insolvenz und Staatsbankrott. Tübingen: Mohr Siebeck, 2011.

139 Ver o discurso de Mirabeau em REICH, E. Selected Documents Illustrating Medieval and Modern History. Honolulu: University Press of the Pacific, 2004 (1905), p. 420.

140 VON DAEHNE VAN VARICK, A. Le Droit Financier International devant la Conférence de la Haie. Haia: M. Nijhoff, 1907, p. 4. "Mais la banqueroute est plus funeste que la guerre: celle-ci peut être juste, celle-là ne l'est jamais, et ajoute donc un mal moral au mal matériel. L'atteinte au bien d'autrui, partant de si haut, trouble la notion de la propriété dans toutes les classes de la société, et ébranle, par conséquent, une des bases de l'ordre intérieur". 
de bancarrota acrescentaria ao mal-estar material um problema moral, com que o Estado não poderia ser indulgente por ameaçar a propriedade privada e a paz internacional. Se a dogmática jurídica alemã utilizaria a expressão para descrever sem meias palavras uma situação de crise e, por outro lado, o senso político francês rejeitaria a conveniência de que o Estado declarasse expressamente a própria penúria, Adam Smith optaria pela transparência do seu emprego, ainda que condenasse o excesso de endividamento que tenha levado à sua necessidade. "Quando é necessário para o Estado se declarar falido (...), uma justa, aberta e confessa bancarrota é sempre a medida menos desfavorável ao devedor e menos danosa ao credor", dizia o economista escocês. A honra do Estado seria mais bem atendida por uma declaração transparente do que pelos truques econômicos usados para diminuir os pagamentos aos credores sem que o Estado o confessasse. ${ }^{141}$

O problema é que os casos e interpretaçôes acima, que apenas incompletamente exemplificam o argumento, não demonstram, por si mesmos, que sob o termo bancarrota se entreveja alguma institucionalidade das crises financeiras do setor público em suas relações com o exterior. Os procedimentos que existem nas ordens jurídicas internas, ao tratarem da bancarrota, não existem em relação aos Estados; os problemas morais não necessariamente se traduzem em formas jurídicas; o direito existente tem fontes diversas que nem sempre encontram canais de diálogo; e, não menos importante, as propostas de mecanismos jurídicos tais como convenções internacionais que disciplinem a bancarrota do Estado esbarram na indisposição dos soberanos em usar uma palavra cuja simples menção afugentaria boa parte de suas fontes de financiamento. O conceito é puramente descritivo de fenômenos financeiros, sem um sentido jurídico preciso, além de ter uma conotação política que por vezes o desaconselha.

Outras noções não são menos problemáticas. A incapacidade de pagamento do Estado, decorra do motivo que for, encontra-se também tratada como uma situação de insolvência, que transpõe ao setor público um conceito de direito privado e se afasta das diferenças que existem entre os instrumentos de política financeira do Estado e a administração das finanças pessoais dos particulares. A esta relativa inaptidão do conceito para se referir com precisão à suspensão da dívida pública do

141 SMITH, A. The Wealth of Nations. Londres: Bantam Classic, 2003 (1776), p. 1185-6. No original, " $[w]$ hen it becomes necessary for a state to declare itself bankrupt, in the same manner as when it becomes necessary for an individual to do so, a fair, open, and avowed bankruptcy is always the measure which is both least dishonourable to the debtor, and least hurtful to the creditor." 
Estado se somam outras dificuldades. Se nos sistemas jurídico-falimentares as declarações falsas de insolvência costumam ser consideradas ilícitas, os credores do Estado, ao lidar com informaçôes financeiras complexas e opacas, teriam dificuldades de monta para aferir se o ente público deixou de pagar suas dívidas por mera vontade ou porque seus balanços não o permitem. A construção de um arcabouço institucional para lidar com a dívida pública dependeria, portanto, de organismos autorizados a decidir esta questão com imparcialidade, ${ }^{142}$ mas mesmo isso não bastaria. $\mathrm{O}$ Estado tem competências que não equivalem às possibilidades dos particulares. O poder tributário, as desapropriações, a emissão de moeda, emissão de novas dívidas, tudo amplia a margem de manobra com que conta o setor público. Uma demonstração irrefutável de que o Estado é insolvente por esgotamento da capacidade financeira é de demonstração dificultosa, uma probatio diabolica, e com algum cinismo se poderia dizer, com apelo às hipóteses extremas, que a incapacidade de pagamento do Estado poderia ocorrer apenas se todos os cidadãos também se tornassem insolventes, portanto incapazes de entregar voluntária ou compulsoriamente recursos aos cofres públicos, e, sobretudo, se a máquina de emissão de moeda parasse de funcionar. ${ }^{143}$ As iniciativas para mitigar o problema da incapacidade de pagamento do Estado, no entanto, indicam a necessidade de considerar as particularidades do setor público sem que se desconsidere totalmente a importância de alguns princípios do direito falimentar. $\mathrm{O}$ tema será desenvolvido no último capítulo.

Mas também aqui se repete o problema não jurídico, e sim político, do estigma conceitual. Muito recentemente, no ano de 2011, o vice-chanceler alemão Philipp Roesler sugeriria procedimentos de "insolvência ordenada" como resposta à crise grega. O pânico gerado no mercado pela declaração seria posteriormente revertido com a atuação do presidente francês Nicolas Sarkozy, que naquela ocasião poderia concordar com Mirabeau a respeito dos efeitos da palavra bancarrota sobre a reputação financeira dos Estados. ${ }^{144}$ Caesar dominus et supra grammaticam: César impera também sobre a gramática, enfatizaria Carl Schmitt a respeito de conceitos

142 É o que já falava BORCHARD, E. State Insolvency and Foreign Bondholders. Washington, D.C.: Beard Books, 1951, p. 116.

143 A crítica ao cinismo desta concepção se encontra em PAULUS, C. Rechtliche Handhaben zur Bewältigung der Überschuldung von Staaten. Recht der Internationalen Wirtschaft, Frankfurt, s. n., 2009, p. 12.

144 Os eventos desta fase da crise financeira europeia podem ser consultados em SHARMA, S. Global Financial Contagion: Building a Resilient World Economy after the Subprime Crisis. Nova Iorque: Cambridge University Press, 2014, p. 163. 
políticos cuja interpretação depende de quem tem o poder de decidir sobre seu uso, bem como seu conteúdo e abrangência. ${ }^{145}$ A composição de um quadro jurídico para a regulação da "insolvência" ou da "bancarrota de Estado" poderia ser assim dificultada pelos processos políticos de decisão sobre o seu significado.

Por fim, quando se fala em default deve-se levar em conta a alteração de seu significado no decorrer do tempo. De origem francesa (do verbo défaillir), a palavra se tornou sinônimo de incapacidade de pagamento quando aplicada às finanças públicas ou pessoais. ${ }^{146}$ Nos sistemas jurídicos anglo-saxões, porém, seu sentido é mais amplo, mais neutro e mais vago. Conquanto possa se referir também à suspensão dos pagamentos de uma dívida em razão do esgotamento dos meios financeiros, a falha no cumprimento de obrigaçôes jurídicas, materiais ou processuais, já poderia caracterizá-lo. Uma prestigiada enciclopédia jurídica inglesa, em edição de 1935, definia o default como “(...) um termo puramente relativo, assim como negligência, não significando nem mais nem menos que o ato de não fazer o que é razoável sob dadas circunstâncias, o ato de não fazer aquilo que se deve, tendo em vista as relaçõos que se estabelecem com outras pessoas interessadas em uma determinada transação." ${ }^{47}$ Por default se costuma entender qualquer violação das obrigações contratuais (não apenas das principais, mas também das acessórias), e ainda a omissão em atos processuais. É por isso que seu significado pode incluir a interrupção do pagamento do principal e dos juros devidos, caso em que coincide com o sentido de bancarrota ou de insolvência, mas a ele não se limita.

A alteração das circunstâncias em que se dará o pagamento e a modificação de obrigações contratuais que não acarretam a demora ou o cancelamento do adimplemento da prestação principal também são descritas como casos de default. Nem todo default, assim, corresponde a uma declaração de insolvência. A substituição de uma garantia contratual, o pagamento em local diferente do estabelecido, ou a alteração da moeda em que a obrigação é denominada são situações amplamente chamadas de default, ainda que não acarretem necessariamente a suspensão dos pagamentos aos credores. Isto não significa que estas alterações possam ter impactos menores sob a percepção do risco das operações de crédito.

145 Positionen und Begriffe (1940). 4. ed. Berlim: Duncker \& Humblodt, 2004, p. 202.

146 Ver, por exemplo, o trabalho de JÈZE, G. Les Défaillances d'État. Recueil des Cours, Leiden, vol. 53, n. 3, 1935, p. 381-434.

147 Halsbury's Laws of England. 2. ed. Londres, 1935, XVI. Tradução livre. No original, o default, “(...) apart from its statutory signification, is a purely relative term, just like negligence, meaning nothing more, nothing less, than not doing what is reasonable under the circumstances, not doing something which one ought to do, having regard to the relations which he occupies towards other persons interested in a particular transaction" 
Tome-se o caso de um Estado que efetue os reembolsos em moeda doméstica, mas proíba a sua conversão ou sua transferência para o exterior. O exemplo não é hipotético. A estratégia econômica do governo dos Estados Unidos para o continente europeu, no início dos anos 30, pretendia evitar a paralisação econômica daquele continente. Para isso foi negociada a moratória Hoover em julho de 1931, que incluía uma série de acordos de suspensão dos pagamentos da dívida (os acordos de standstill) pelo prazo de um ano, o que incluía as reparações de guerra devidas pela Alemanha. A despeito disso, o governo alemão prometera manter os pagamentos denominados em moeda estrangeira, implementando, no entanto, uma série de controles de capitais que pretendiam limitar sua fuga para o exterior. ${ }^{148} \mathrm{O}$ default pode se definir, desse modo, não apenas pela interrupção dos pagamentos, mas por medidas tomadas por um Estado que alterem as circunstâncias em que ele deve ocorrer, tais como por meio do controle de transferências.

Referências mais recentes qualificam o default, no entanto, como a demora ou a interrupção dos pagamentos, o que lhe confere uma conceituação acentuadamente financeira. Fala-se em default parcial nos casos de interrupção do serviço de uma parte da dívida pública, como ocorre, por exemplo, com o não pagamento do principal no período aventado, mas com a continuidade do adimplemento dos juros incidentes. A noção correlata, de default total, se identifica com a paralização de todos os pagamentos aos credores das obrigações financeiras do Estado. Neste último sentido, o default se aproxima da ideia de moratória, que bem o traduziria em sua acepção pragmática contemporânea. ${ }^{149} \mathrm{~A}$ agência de avaliação de riscos Moody's define a situação de default como aquela em que se cancela ou se atrasa o reembolso do principal ou dos juros devidos, mesmo que o pagamento seja feito dentro de um período de graça, caso houver. De modo similar, a conceituação oferecida pela Standard and Poor's é a de falha em atender ao pagamento do principal ou dos juros no prazo devido (ou dentro do período de graça) previsto nos termos iniciais da emissão da dívida. ${ }^{150}$ Com este sentido, o default se aproxima de bancarrota ou

148 KLUG, A. The German Buybacks, 1932-1939: a Cure for Overhang?. Princeton Studies in International Finance, Princeton, n. 75, nov. 1993, p. 1-80.

149 DAS, U.; PAPAIOANNOU, M.; TREBESCH, C. Sovereign Debt Restructurings 19502010: Literature Survey, Data, and Stylized Facts. Washington, D.C.: FMI, 2012, p. 8.

${ }^{150}$ Ver a compilação destas definições em PESCATORI, A.; SY, A. Are Debt Crisis Adequately Defined? IMF Staff Papers, Washington, D.C., vol. 54, n. 2, 2007, p. 308-309. Pela Moody's, surge o default quando "there is a missed or delayed disbursement of interest and/or principal, even if the delayed payment is made withing the grace period, if any" (destaque do original). Pela Standard \& Poor's, qualifica-se o default por "the failure of an obligor to meet a principal or interest payment on the due date (or withing the specified grace period) contained in the original terms of the debt issued". 
insolvência, ainda que eventualmente possa se referir a alterações em formas e condiçôes de pagamento que não signifiquem (ao menos imediatamente) uma desvantagem patrimonial aos credores.

Os três conceitos aqui tratados remetem a um dado estado de coisas que, aproximativamente, pode ser como uma situação de inadimplemento da dívida pública - seja porque os pagamentos não foram feitos, seja porque se deram em condições diferentes daquelas inicialmente pactuadas. A bancarrota, a insolvência e o default são conceitos descritos que indicam a interrupção do serviço da dívida, o que ao menos parte da literatura econômica chamaria de crise da dívida pública. ${ }^{151}$ Em análises nas quais importa mais a capacidade descritiva dos conceitos do que a referência a características tecnicamente mais bem definidas, o uso corriqueiro e a capacidade conotativa desses termos não podem ser desprezados. Há, no entanto, contextos que requerem maior especificação, como aqueles em que se busca a identificação de um regime jurídico próprio da dívida pública. Neste caso, os termos acima têm um significado amplo e vago, ainda que consigam apontar para algumas características relevantes e confiram uma noção mais ou menos competente sobre suas configurações mais gerais. As crises da dívida pública têm, para o direito financeiro, um sentido próprio, que se desloca em algumas de suas categorias operacionais contidas no conceito mais amplo de inexecução da dívida pública. As crises no serviço da dívida podem ter um sentido delimitado na linguagem do sistema econômico (de onde advém seu potencial denotativo), assim como fica sujeita à calibragem da linguagem política utilizada pelos diversos atores envolvidos na denominação de determinados eventos como bancarrota, insolvência ou default do Estado. É o sistema jurídico, por sua vez, que permite qualificar as estruturas formais de modificação e extinção das obrigações que constituem a dívida pública, aqui amplamente tratadas como hipóteses de sua inexecução, por meio das quais o Estado não as sirva no modo ou tempo originalmente estabelecidos.

\subsection{FORMAS DE INEXECUÇÃO DA DÍVIDA PÚBLICA}

Ainda que seja possível cogitar de casos em que o Estado cancele, pura e simplesmente, o pagamento da dívida pública, não é esta a única forma pela qual a

151 É o que faz J. Sachs, ao analisar os riscos na continuidade do serviço da dívida a partir de diversas hipóteses de default. Cf. Theoretical Issues in International Borrowing. Princeton Studies in International Finance, Princeton, n. 54, jul. 1984, p. 1-46. Em sentido contrário, aponta-se que nem todas crises da dívida pública decorrem de dificuldades em manter o seu serviço (vide PESCATORI, A.; SY, A. Are Debt Crisis Adequately Defined? IMF Staff Papers, Washington, D.C., vol. 54, n. 2, 2007, p. 306-337). 
situação de default acima descrita passa a existir. Também a demora no pagamento e as modificaçôes contratuais comprometem o serviço da dívida. Podem ser preliminarmente descritas, portanto, três hipóteses de inexecução: aquela em que a obrigação se extingue por ato unilateral; aquela em que os pagamentos são adiados com prazo certo ou indeterminado; e ainda aquela em que as obrigaçôes originais são convertidas em novas obrigações, normalmente com a intenção de modificar o principal ou os juros devidos.

Seria desnecessário dizer que o tema se situa, portanto, na fase de cumprimento ou de execução das obrigações, campo em que aquelas que constituem a dívida pública financeira do Estado obedecem aos elementos gerais das obrigações tais como analisadas pela teoria jurídica. Todas se desenvolvem em etapas encadeadas, como um processo que se sucede em fases. Após o surgimento das obrigações, é lícito esperar que, em suas fases finais, o adimplemento represente a solução natural da obrigação, o cumprimento do fim para o qual ela foi criada. Neste ponto, um critério classificatório é útil para que se possam colocar em uma sistematização coerente as formas de inexecução da dívida pública. As obrigações se extinguem de forma satisfatória ou de forma não satisfatória. Interessa, aqui, saber do quadro jurídico para as soluções não satisfatórias aos interesses que serviram de base à conformação primeira da relação jurídica entre o Estado e seus credores.

Se, de um lado, o adimplemento da obrigação é causa extintiva satisfatória, que atende à finalidade do acordo entre as partes, os modos não satisfatórios são aqueles em que o adimplemento tardio ou o inadimplemento absoluto, ou ainda alterações unilaterais obrigatórias ou forçadas, contrariam as pretensões iniciais. ${ }^{152}$ Uma referência essencial sobre o assunto na doutrina jurídica brasileira qualificaria ambos os contextos com uma imagem orgânica, e falaria de um estado fisiológico das obrigaçôes, que supõe a normalidade de seu curso, e de seu fenômeno oposto, o estado patológico, em que o combinado é infringido e cuja infração provoca o surgimento de determinadas consequências jurídicas. ${ }^{153}$ As muitas crises da dívida pública atestam a frequência da patologia, o fato comum do descumprimento das obrigaçôes, que lança às estruturas que formalmente lidam com estes casos a necessidade de distinguir as formas pelas quais a inexecução se manifesta. Elas são esquematizadas como situaçõos de modificação, de um lado, e de inadimplemento das obrigações, com ou sem sua extinção, de outro.

152 MAJO, A. d. Obbligazione. In: Enciclopedia Giuridica. Roma: Instituto della Enciclopedia Italiana, 2007, vol. XXIV, p. 33 e seguintes.

153 AGOSTINHO ALVIM. Da Inexecução das Obrigações e suas Consequências. São Paulo: Saraiva, 1949, p. 11. 
Algo deve, ainda, ficar claro. Ao se falar, por exemplo, em extinção de uma obrigação financeira do Estado, fala-se de uma dada obrigação, aquela estabelecida entre o Estado e outra parte, seja ela qual for; não se quer com isso dizer, necessariamente, que se tenha extinguido a totalidade da dívida pública, aqui tomada como o estoque acumulado até dado momento. Interessa, juridicamente, o modo como se extinguem as obrigações específicas, e ela corresponderia à extinção da dívida pública apenas se o Estado tivesse somente um credor e com ele houvesse firmado apenas uma operação de crédito. Esta ressalva deve evitar que expressões como modificação ou extinção da dívida pública sejam tomadas em sentido demasiadamente literal. Pretende também evitar a impressão de que este trabalho teorizasse de alguma forma sobre conceitos econômicos de redução ou gestão da dívida pública. Com seu sentido jurídico, as obrigações que a compõem serão tomadas isoladamente, pois as diferentes categorias já expostas submetem-se também a distintos regimes que não podem ser tomados em sua globalidade.

\subsubsection{Formas modificativas}

As obrigações financeiras do Estado podem ser modificadas quanto ao seu objeto ou quanto a seus sujeitos. Ao falar de modificaçôes objetivas, serão analisadas as reestruturações ou conversões da dívida pública. As modificações subjetivas, por sua vez, referem-se aos casos de sucessão de Estados.

\subsubsection{Modificações objetivas explícitas. Reestruturação, conversão e consolidação}

Independentemente da denominação que se dê à inexecução do serviço da dívida pública, os Estados, ao afirmarem que sua carga de endividamento insustentável, com alguma rotina decidem por alterar o modo de pagamento de seus débitos. Haveria outras formas pelas quais um Estado altamente endividado, cuja capacidade financeira alegue estar esgotada, ou indisposto a satisfazer as obrigações financeiras em detrimento de outras finalidades que resolva dar a seus recursos, poderia interromper, temporária ou definitivamente, os pagamentos da dívida pública. Os meios de extinção de uma obrigação financeira, tais como a declaração formal da não intenção de pagar determinada classe de credores, não excluem, no entanto, formas menos drásticas de descumprimento dos contratos inicialmente firmados. Nestes casos, um Estado pode alterar as condiçôes originais de pagamento. Estas modificações constituem os procedimentos de reestruturação da dívida pública, de que se fala quando o Estado altera os pagamentos inicialmente fixa- 
dos, com ou sem sua suspensão, ainda que, normalmente, sob a ameaça de fazê-lo. ${ }^{154}$ O propósito de uma modificação desse tipo é tornar a dívida pública administrável em um contexto no qual a preservação das condições iniciais de pagamento colocaria a continuidade das atividades do Estado sob excessiva pressão; isto é, confere-se aos passivos públicos um perfil mais gerenciável. Outra finalidade que se poderia alcançar é a redução do valor líquido da dívida pública. É inevitável associar este processo de reestruturação a crises financeiras do Estado, que se manifestem pela insuficiência dos recursos orçamentários ou por gastos públicos pressionados. A ideia de crise é plurívoca, mas, ao menos sob a perspectiva fiscal, qualquer uma das duas finalidades acima, que se apresentam como resposta a dificuldades financeiras, poderia ser atingida se, tudo o mais constante, o Estado reestruturasse satisfatoriamente sua dívida. Pode ser que o faça de forma mais ou menos abrangente, com ou sem o consenso dos credores, dispondo de maior ou menor confiança sobre a sinceridade de sua afirmação de que a dívida pública é, de fato, insustentável. Quer modifique os pagamentos por não ser financeiramente capaz de lhes dar continuidade ou porque entenda que seja esta a forma mais adequada de liberar recursos para outros fins, as receitas públicas podem ser aliviadas com as medidas de reestruturação.

A terminologia não é uniforme. Reestruturação e conversão podem ser tomadas como palavras sinônimas, pois se referem a um mesmo grupo de estruturas formais de modificação das obrigações financeiras. ${ }^{155}$ Conquanto o primeiro termo tenha se tornado recentemente mais comum, ambos tratam da novação de determinadas obrigações, com sua transformação em outras menos onerosas. ${ }^{156} \mathrm{~A}$ mudança da nomenclatura pode indicar também uma alteração de ênfase. Se a categoria técnica das conversóes parece indicar os procedimentos adotados pela autoridade pública para transformar pontualmente determinadas obrigaçôes, a reestruturação transmite a ideia mais ampla de redefinição de toda uma classe da

154 STURZENEGGER, F.; ZETTELMEYER, J. Debt Defaults and Lessons from a Decade of Crises. Cambridge: the MIT Press, 2006, p. 3; WAIBEL, M. Sovereign Defaults before International Courts and Tribunals. Cambridge: Cambridge University Press, 2011, p. 14.

155 Entre as obras clássicas que tratam do assunto, v. JĖZE, G. Science des Finances et de Législation Financière Française. 6. ed. Paris: Marcel Giard, 1922, p. 307 e seguintes; LABEYRIE, H. Théorie et Histoire des Conversions de Rentes. Paris: Guillaumin et Cie., 1878, p. 57. Ambos se referem à conversão da dívida pública, e não mencionam o termo reestruturação.

156 Sobre a equivalência de efeitos da conversão e da novação tal como tratada pelo direito das obrigaçôes, ver FONROUGE, C. Derecho Financiero. 3. ed. Buenos Aires: Depalma, 1977, vol. 2, p. 1046. 
dívida pública que apresente um dado perfil, de uma abrangente política de alteração dos pagamentos da dívida pública de que o espetacular default argentino de 2001 seria o exemplo emblemático. Tanto o volume da dívida reestruturada como os conflitos de interesses entre o Estado e algumas das classes de credores indicam a amplitude do problema, que não se deixaria entrever por denominações mais tímidas que se referissem a contratos individualizados. De fato, por vezes o termo conversão é utilizado de forma muito restrita para algumas modalidades de modificações objetivas dos contratos, ora exclusivamente à alteração do capital, ora apenas à mudança dos juros nominais. ${ }^{157}$ Por esta razão fala-se mais frequentemente em reestruturação, ainda que não houvesse ambiguidade caso o termo conversão fosse tomado de forma menos restrita.

Por meio da reestruturação, o Estado reembolsa uma dada categoria de credores pela emissão de um novo título constituído em diferentes condições. Sob o ponto de vista cronológico, a modificação das obrigaçôes originais representa também sua extinção; estas obrigaçôes são, no entanto, substituídas por outras de modalidade distinta. A relação jurídica do Estado com os credores e os efeitos financeiros do endividamento sobre as finanças públicas prosseguem, portanto. Por esta razão as formas modificativas serão aqui tratadas separadamente dos modos de extinção das obrigações.

Em que consistem, porém, tais modificaçôes? Não há, na realidade, um só fim, ou um só modo. Quanto às finalidades, as reestruturações podem se destinar a reduzir os juros, o principal, ou ambos, e ainda estender os prazos de pagamento; e, quanto ao modo, podem ser forçadas ou voluntárias. Em todo caso o Estado deixará de atender ao propósito primeiro ao qual as partes aderiram no momento de constituição das obrigações. Tome-se primeiramente a finalidade das reestruturaçôes, a redução dos juros ou do principal, um modo não satisfatório de transformação das obrigações originais se levados em conta os valores financeiros inicialmente estipulados, bem como os prazos de pagamento. ${ }^{158}$ Trata-se, portanto, de

157 LAPATZA, J. Curso de Derecho Financiero Español. 23. ed. Madri: Marcial Pons, 2003, vol. I, p. 279. Como exemplo de conceituação da conversão apenas como a transformação das taxas de juros, ver INGROSSO, G. Corso di Finanza Pubblica. Napoli: Casa Editrice Dott. Eugenio Jovene, 1969, p. 576: "[1] a conversione (...) consiste nel sostituire ad un determinato tasso di interesse, un debito da contrarsi ad un tasso d'interesse inferiore".

158 Para a distinção entre o default do principal e dos juros, cf. BORCHARD, E. State Insolvency and Foreign Bondholders. Washington, D.C.: Beard Books, 1951, vol. 1, p. 123-8; MADDEN, J.; NADLER, M. Foreign Securities: Public and Mortgage Bank Bonds - an Analysis of the Financial, Legal and Political Factors. Nova Iorque: The Ronald Press Company, 1929,, p. 264 e seguintes. 
uma operação financeira de transformação da relação jurídica inicial entre o Estado e o credor. Aqui algo deve ser apontado com mais cuidado. Toda reestruturação seria desfavorável aos credores? Dois aspectos precisam ser aqui considerados.

Seria possível, ao menos em tese, cogitar de reestruturações favoráveis aos credores, ou seja, de casos em que as obrigaçôes originais fossem alteradas em vantagem daqueles a quem os pagamentos devem ser feitos. É verdade que haveria poucos exemplos históricos, os quais, no entanto, existem. Em 1949, o governo francês ofereceu a alguns dos detentores de títulos de menor valor a possibilidade de trocar papeis a 3\% por outros a 5\%, e a Argentina, em 1960, abriu a possibilidade de que alguns títulos novos a $8 \%$ fossem dados em pagamento a portadores de outros certificados com juros menores, caso optassem por fazê-lo durante o período de subscrição dos novos títulos. A intenção, nestes casos, foi conferir um auxílio direto para a recuperação econômica de algumas classes especiais de credores (notadamente aqueles com problemas econômicos agudos) ou readequar o perfil da dívida pública a circunstâncias mais atuais. ${ }^{159}$

Estes casos, porém, são tão atípicos que recebem o nome de anti-conversões. Eles tomam uma considerável distância do propósito normal das operações de reestruturação da dívida pública, que têm normalmente o objetivo de reduzir os pagamentos devidos pelo Estado, e não os aumentar. As reestruturações costumam se dar com algum prejuízo para os interesses dos credores, o que parece ter se agravado ao longo do tempo. Há estudos que procuraram quantificar, em determinados períodos, a dimensão das perdas em processos de reestruturação. Veja-se o extenso trabalho de Suter, que compara as reestruturações nos períodos de 1820 a 1870, de 1871 a 1925 e de 1926 a $1975 .{ }^{160}$ Considerando o pagamento dos juros em atraso, a redução das taxas de juros e a diminuição do valor de face dos títulos, as modificações se tornaram mais desvantajosas aos credores ao longo do tempo. No primeiro desses períodos, mal se podia falar em cortes no valor nominal dos títulos, com reduçôes de juros da ordem de $15 \%$ e cerca de $81 \%$ dos reembolsos atrasados transformados em novos títulos. No segundo período, os percentuais da redução do valor de face, dos juros e da capitalização dos pagamentos em atraso foram, respectivamente, de $23 \%, 16 \%$ e $72 \%$ (com a ressalva de que a diminuição do valor nominal teria sido um reflexo da substituição do pagamento em dinheiro por terras e concessões públicas do setor de infraestrutura). O período do entreguerras,

159 Os casos são citados em FONROUGE, C. Derecho Financiero. 3. ed. Buenos Aires: Depalma, 1977, vol. 2, p. 1048.

${ }^{160}$ Debt Cycles in the World Economy: Foreign Loans, Financial Crises, and Debt Settlements, 1820-1990. Boulder: Westview, 1992. 
por sua vez, foi aquele em que as perdas se mostraram ainda mais volumosas, com valores de face em média $23 \%$ menores, decréscimo de $34 \%$ nos índices de juros e o reconhecimento de apenas $35 \%$ dos pagamentos atrasados. Outras pesquisas acompanham as perdas em tempos mais recentes. Na década de 1980, as negociações no bojo do plano Brady significaram descontos que variaram de $35 \%$ no caso do México até $76 \%$ no da Costa do Marfim, algo que, ao menos para a perspectiva dos credores, se agravaria ainda mais com a redefinição dos prazos de maturidade para períodos mais longos. ${ }^{161}$ De 1998 a 2005, os investidores em títulos públicos sofreram perdas significativas no valor de face dos títulos nos processos de reestruturação da dívida russa (2000), ucraniana (2000), equatoriana (2000) e argentina (2005), e significativas extensões na maturidade dos empréstimos nas renegociações paquistanesa (1999) e uruguaia (2003). A redução no valor ao par variou de 5 a $20 \%$ no caso do Uruguai até $70 \%$ no exemplo da Argentina. ${ }^{162}$

Não surpreende que, diante de perdas que se avolumam, as reestruturações tenham se tornado um problema jurídico relevante em razão da litigiosidade que incentivam. Trata-se de um problema que diversas instâncias nacionais e instituições internacionais são chamadas a enfrentar. Mas não apenas a pressão sobre os valores, os rendimentos, os juros e o pagamento de parcelas em atraso dos empréstimos públicos são potenciais elementos conflitivos. Outro fator estrutural que caracteriza os procedimentos de reestruturação pode ser responsabilizado pelo papel mais atuante de instituições jurídicas nas reestruturações, e esse elemento é o consentimento dos credores. $\mathrm{O}$ acorrimento de sua vontade permite distinguir diferentes tipos de reestruturação, e aqui se chega a um aspecto. É preciso distinguir as conversões por uma classificação que as caracterize como forçadas ou voluntárias, nesta segunda categoria compreendidas aquelas de natureza facultativa ou obrigatória. Não deve estranhar que se fale, nestes casos, de conversões simultaneamente voluntárias e obrigatórias, desde que compreendido seu exato significado. ${ }^{163}$

As reestruturações forçadas são tomadas por decisão unilateral do Estado, por meio de ato de autoridade, e não oferecem ao credor a possibilidade de se subtrair à determinação estatal. Assim, por exemplo, as reduções unilaterais de juros. Está

161 RIEFFEL, L. Restructuring Sovereign Debt: the Case for Ad Hoc Machinery. Washington, D.C.: Brookings Institution Press, 2003, p. 171.

162 STURZENEGGER, F.; ZETTELMEYER, J. Haircuts: Estimating Investor Losses in Sovereign Debt Restructurings, 1998-2005. Washington, D.C.: FMI, 2005.

163 Ao menos quanto a este critério, a classificação não encontra alterações significativas na doutrina do direito financeiro. A referência fundamental continua a ser JĖZE, G. Science des Finances et de Législation Financière Française. 6. ed. Paris: Marcel Giard, 1922, p. 390-391. 
claro que, nestes casos, ocorre um ato antijurídico, uma violação dos contratos, algo que reconheceriam, já desde muito tempo, até mesmo aqueles que afirmam a natureza de ato jurídico unilateral dos empréstimos públicos. ${ }^{164}$

As reestruturações voluntárias, por sua vez, oferecem duas alternativas aos credores. A primeira delas é deixar livre o caminho da adesão à oferta pública de troca dos títulos, que não é obrigatória, e aqui se fala em reestruturação facultativa. Outra possibilidade é apresentar aos investidores o "dilema financeiro clássico"165 de ter que escolher entre aceitar a oferta de reestruturação do Estado ou a extinção das obrigações originais com o recebimento dos valores nominais. As ofertas de troca do tipo "pegar ou largar"166 são conversões que não perdem seu caráter voluntário (pois ainda dependem do consentimento do credor), mas que o colocam diante de uma escolha que será apenas a menos pior diante de determinadas circunstâncias econômicas. O sucesso de uma conversão obrigatória dependeria do cumprimento de condições objetivas, entre as quais já se apontou a credibilidade do Estado, a cotação dos títulos convertíveis acima do valor nominal (de modo que o credor que não aceite a oferta se coloque diante de uma desvantagem financeira) e a cotação taxas de juros de mercado inferiores àquela oferecida aos possuidores dos títulos. ${ }^{167}$ Mas, nestes casos, ainda que o credor adira à oferta, haverá algum grau de coercitividade que dificilmente permitiria concluir que a solução consensual era aquela pretendida pelos portadores dos títulos quando o adquiriram. Neste sentido, a não ser nas raras hipóteses de anti-conversões destacadas previamente, as reestruturações costumam se dar em detrimento dos interesses dos credores.

É possível encontrar, ainda, diferentes denominações para cada um dos fenômenos aqui referidos como reestruturaçôes, o que admite partir a uma tipologia de cada uma destas categorias de acordo com a sua denominação menos infrequente. A maior parte das reestruturações se dá sob a forma de reescalonamento, que são os prolongamentos da maturidade das obrigações antigas, com o possível envolvimento de taxas de juros menores. Como estes diferimentos negociados implicam a extensão dos prazos de pagamento, representam também uma forma de amenização

164 FONROUGE, C. Derecho Financiero. 3. ed. Buenos Aires: Depalma, 1977, vol. 2, p. 1047.

165 A expressão é de LAPATZA, J. Curso de Derecho Financiero Español. 23. ed. Madri: Marcial Pons, 2003, vol. I, p. 279.

166 Cf. WAIBEL, M. Sovereign Defaults before International Courts and Tribunals. Cambridge: Cambridge University Press, 2011, p. 14.

167 INGROSSO, G. Corso di Finanza Pubblica. Napoli: Casa Editrice Dott. Eugenio Jovene, 1969, p. 578-580; GRIZIOTTI, B. Principioes de Ciencia de las Finanzas. Buenos Aires: Depalma, 1959, p. 392. 
do impacto do serviço da dívida, e daí que sejam mencionadas como instrumentos de alívio do endividamento. Há, no entanto, formas mais diretas de promoção de reduçôes nos pagamentos, com a diminuição ipso facto do valor de face dos títulos e dos juros incidentes, vencidos ou vincendos. Os reescalonamentos são formas de reestruturação mais comum que as reduções diretas, ainda que ambos acarretem algum tipo de diferença entre os valores atuais de mercado de compra e de venda do título (o que se chama de haircut). Finalmente, uma terceira categoria referida entre as formas de reestruturação é a recompra de títulos da dívida pública (debt buybacks), por meio da qual as obrigaçōes pendentes são trocadas por pagamento em espécie, geralmente com descontos. Trata-se de uma resposta mais incomum às potenciais crises de pagamento da dívida pública. ${ }^{168}$

\subsubsection{Modificações objetivas implícitas: reforma monetária}

Nem todas as modificações contratuais são, porém, declaradas. Instrumentos financeiros da soberania do Estado são utilizados para reduzir o valor dos pagamentos aos credores sem que se efetue um procedimento formal de reestruturação, com ofertas de trocas dos títulos. Pelo seu poder de promover alguma forma de reforma monetária que recaia sobre os títulos da dívida pública, o Estado pode reduzir o valor dos reembolsos em detrimento do inicialmente pactuado, sem que assim o declare.

A primeira das competências acima mencionada, a soberania monetária do Estado, é reconhecida pelo direito internacional público, e, por consequência, o valor da moeda é passível de determinação pelo Estado que a emite. O exercício do poder de regular a própria moeda atende a diferentes objetivos macroeconômicos, um dos mais comuns a manutenção da inflação sob controle. A dívida pública pode também ser administrada por meio de ajustes no valor da moeda, desde que aptos a conduzi-la a níveis sustentáveis. Há, na regulação monetária, um aspecto da soberania do Estado que diz respeito à preservação de seu equilíbrio econômico. $\mathrm{O}$ reconhecimento desta competência faz parte da opinião comum, de um "princípio universalmente aceito", como menciona a Resolução n. 1.103/97 da Comissão Europeia, ao tratar de medidas para a introdução do euro no bloco comunitário. ${ }^{169}$

168 A propósito destas distinçôes e de uma extensa documentação de casos de reescalonamento e reduçōes, cf. DAS, U.; PAPAIOANNOU, M.; TREBESCH, C. Sovereign Debt Restructurings 1950-2010: Literature Survey, Data, and Stylized Facts. Washington, D.C.: FMI, 2012, p. 7 e seguintes.

169 COMISSÃO EUROPEIA. Council Regulation n. 1.103/97, de 17 de junho de 1997. OJ L 162, 19/06/1997, p. 3. No original, "[w] hereas the introduction of the euro constitutes a 
Além disso, adota-se o nominalismo como regime aceito para as obrigações de pagar em dinheiro, que devem ser adimplidas, como regra, pelo seu valor nominal. ${ }^{170}$ Isto significa que uma obrigação de pagar é adimplida se o credor, no momento de seu vencimento, pagar ao devedor o valor nominalmente fixado, independentemente das variaçõos no valor intrínseco da moeda eventualmente ocorridas entre a constituição e o fim da obrigação, ainda que, em alguns casos, se possa determinar, por imposição legal ou convencional, o ajuste monetário às variações no valor monetário real.

Tudo até aqui poderia indicar que o exercício das competências monetárias do Estado e a aceitação do nominalismo nas obrigações de pagar como uma norma amplamente reconhecida em diversas ordens jurídicas fariam das variações no valor real da unidade de pagamento algo incapaz de caracterizar o não cumprimento dos contratos. Pela lex monetae válida em determinado lugar, aqueles que portam, transferem e recebem o papel-moeda se sujeitam à regulação de seu valor pela autoridade que o emitiu. Há casos, no entanto, em que as mudanças monetárias extrapolam o exercício normal da regulação e, alterando significativamente a estrutura do sistema monetário até então vigente, podem configurar violação das obrigações financeiras do Estado. Nestes casos, atenta-se não apenas para a lex monetae, mas também para a lex contratus, de maneira que o direito do local em que se celebrou o contrato defina o eventual descumprimento de deveres estabelecidos entre as partes. Os limites entre o exercício legítimo da competência monetária e a prática ilícita, que se chamaria de um default implícito, foi o que tentaram definir algumas decisões judiciais fundamentais da Corte Permanente de Justiça Internacional (CPJI). Os casos dos empréstimos sérvios e brasileiros, ambos julgados em 1929, trataram de alterações substanciais na unidade monetária adotada como meio de pagamento de parte da dívida pública e de suas consequências sobre obrigações financeiras anteriormente firmadas.

Diversas questões relevantes ao regime jurídico das alterações monetárias no pagamento da dívida pública foram decididas nesses casos, algumas das quais pertinentes à lei aplicável aos contratos (e enquadráveis, neste sentido, no direito internacional privado de algum Estado nacional) e outras que dizem respeito à licitude da conduta dos Estados sérvio e brasileiro perante princípios gerais de Direito

change in the monetary law of each participating Member State; whereas the recognition of the monetary law of a State is a universally accepted principle (...)"

170 F. Mann aponta o nominalismo como um princípio fundamental dos regimes jurídicos da moeda nos países ocidentais. Cf. The Legal Aspect of Money. ed. Londres: Oxford University Press, 1938, p. 60-61. 
válidos para a comunidade internacional, tais como o dever de boa-fé e de tratamento equitativo. Os casos podem ser examinados em conjunto, por se referirem a fatos bastante semelhantes. ${ }^{171}$

A primeira questão a ser analisada diz respeito ao direito aplicável a contratos cujo cumprimento deve se dar em conjunturas nas quais os pagamentos são feitos em moeda que sofreram alteraçooes profundas de valor. Caso se tratasse de uma desvalorização não amparada por cláusulas contratuais protetivas, as flutuações monetárias seriam um risco inerente a qualquer operação em papel-moeda, uma parte das vicissitudes a que se submetem tanto credores como devedores ao lidarem com taxas internacionais de câmbio e com os poderes de um Estado estrangeiro sobre a emissão de sua moeda. ${ }^{172}$ Havia nos contratos firmados entre os governos sérvio e brasileiro com credores franceses, entretanto, a previsão contratual de cláusulas-ouro, que asseguravam a manutenção do valor real do dinheiro devido pelo seu atrelamento a uma moeda que tivesse por base o padrão-ouro. No caso dos empréstimos brasileiros, esta moeda seria o próprio ouro para os juros payable en or de empréstimos tomados em 1909 e para o principal e juros de outras operações realizadas em 1910 e 1911, cujos recursos haviam sido destinados à construção do porto de Recife e de estradas de ferro em Goiás e na Bahia. ${ }^{173} \mathrm{O}$ caso sérvio, a seu turno, girava em torno da disputa pelo pagamento de títulos lançados pelo governo daquele país, em 1895, em favor de consórcios bancários em sua maioria sediados em Paris, os quais continham cláusula-ouro segundo a qual o pagamento seria feito em francos-ouro (i.e., francos conversíveis em ouro). A Sérvia concordava em usar o ouro ou moeda equivalente (como o franco-ouro) para a amortização e o serviço da dívida, medida necessária para neutralizar a inflação e a manipulação cambial. ${ }^{174}$

171 Segundo WAIBEL, contemporaneamente os casos seriam unificados como o caso dos empréstimos sérvios e brasileiros (Sovereign Defaults before International Courts and Tribunals. Cambridge: Cambridge University Press, 2011, p. 60).

172 BORCHARD, E. State Insolvency and Foreign Bondholders. Washington, D.C.: Beard Books, 1951, vol. 1, p. 137. Segundo o autor, "[b] ondholders frequently sustain injury because the currency in which the debt is expressed depreciates during the life of the loan by changes in the monetary standard. In the absence of special devices in the loan contract designed to guard against this contingency, such as gold clauses or currency options, the risk of currency depreciation must be borne by the creditor".

173 CPJI, Case Concerning the Payment in Gold of the Brazilian Federal Loans Issued in France, série A, n. 15, 1929, p. 97-99.

174 CPJI, Case Concerning the Payment in Gold of the Brazilian Federal Loans Issued in France, série A, n. 15, 1929, p. 9-14. 
Depois da Primeira Guerra, no entanto, grande parte dos países enfrentou problemas para sustentar os pagamentos financeiros, o que se agravou com os elevados índices de inflação. $O$ resultado foi que o franco francês perdeu cerca de $80 \%$ de seu valor. Até 1924, o governo sérvio pagava estes empréstimos em francos franceses, a moeda corrente emitida pela França, sem que isto significasse desvantagens aos credores, pois se tratava de uma moeda cujo valor tinha o ouro como lastro. ${ }^{175} \mathrm{O}$ mesmo fizera o governo brasileiro até aquele ano. ${ }^{176} \mathrm{~A}$ partir da grande desvalorização do franco, no entanto, os credores passaram a recusar o pagamento em papel-moeda e exigiram o cumprimento da cláusula-ouro que assegurava a preservação do valor real dos meios de pagamento. Após alguma relutância, o governo francês decidiu exercer a proteção diplomática de seus nacionais, em litígio com os governos brasileiro e sérvio. Mediante os pedidos de Sérvia e França, em um caso, e do Brasil e França, em outro, a Corte Permanente foi chamada a se pronunciar sobre a disputa. Ainda que se tratasse de um litígio contratual, a Corte reconheceu sua competência por não poder se furtar à apreciação de uma controvérsia submetida por dois Estados. ${ }^{177}$

Após o reconhecimento da própria competência, a questão a ser decidida pela Corte era a validade dos pagamentos em moeda desvalorizada, que tanto o governo brasileiro como o governo sérvio defendiam em razão do princípio do nominalismo, amparado pelo Código Civil francês. ${ }^{178}$ Como os credores haviam aceitado o

175 CPJI, Case Concerning the Payment in Gold of the Brazilian Federal Loans Issued in France, série A, n. 15, 1929, p. 14.

176 CPJI, Case Concerning the Payment in Gold of the Brazilian Federal Loans Issued in France, série A, n. 15, 1929, p. 100.

177 Nos termos do que dispunha o art. 36(1) do Estatuto CPJI, The jurisdiction of the Court comprises all cases which the parties refer to it and all matters specially provided for in treaties and conventions in force. The Members of the League of Nations and the States mentioned in the Annex to the Covenant may, either when signing or ratifying the Protocol to which the present Statute is adjoined, or at a later moment, declare that they recognize as compulsory ipso facto and without special agreement, in relation to any other Member or State accepting the same obligation, the jurisdiction of the Court in all or any of the classes of legal disputes concerning: (a) the interpretation of a treaty; (b) any question of international law; (c) the existence of any fact which, if established, would constitute a breach of an international obligation; (d) the nature or extent of the reparation to be made for the breach of an international obligation." (Statute of the Permanent Court of International Justice, de 16 de dezembro de 1920).

178 Segundo o artigo 1895, “[1]'obligation qui résulte d'un prêt en argent n'est toujours que la somme numérique énoncée au contrat. S'il y a eu augmentation ou diminution d'espèces avant l'époque du paiement, le débiteur doit rendre la somme numérique prêtée, et ne doit rendre que cette somme dans les espèces ayant cours au moment de paiement." 
recebimento em francos em papel até aquele momento, alegava-se ainda o estoppel, que precluía a invocação da cláusula-ouro em sua defesa. A primeira matéria a ser decidida pela Corte seria, por conseguinte, o parâmetro normativo que definiria a licitude dos pagamentos em moeda não lastrada pelo ouro.

No caso dos empréstimos sérvios, estabeleceu-se o conhecido princípio de que um contrato que não é firmado entre Estados está sujeito à lei interna de algum país. ${ }^{179}$ A questão se tornava saber se a obrigação financeira se sujeitava, então, à lei sérvia e brasileira, conforme o caso, ou à lei francesa. De modo mais concreto, esta pergunta pretendia determinar se à moeda de pagamento da dívida pública se aplicaria o direito interno do Estado emissor dos títulos ${ }^{180}$ ou do Estado regulador da moeda em que se realizam os pagamentos. Ambas as decisões cindiram, então, o direito aplicável às obrigações financeiras externas do Estado, por meio de uma distinção, vagamente antevista acima, entre a lex monetae e a lex contractus; a primeira aplicável ao meio de pagamento, e a segunda ao conteúdo da obrigação.

Não chega a ser alguma excepcionalidade que tribunais aos quais compita a aplicação do direito internacional tenham que examinar normas de direito interno. ${ }^{181}$ Considerada a intenção dos Estados emissores, dois argumentos foram levados em consideração para a construção da decisão a propósito da lei aplicável ao conteúdo da obrigação. $\mathrm{O}$ primeiro, o de que não estava demonstrado que, ao lançar os títulos, os governos sérvio ou brasileiro tinham a intenção de se submeter a alguma ordem jurídica estrangeira. $\mathrm{O}$ segundo remetia a um princípio equitativo. Como são muitas as jurisdições em que os títulos são oferecidos, haveria um desigual tratamento entre os credores de diferentes nacionalidades caso ficassem sujeitos a distintas leis aplicáveis. A obrigação financeira do Estado é disciplinada, em sua substância, pela lei interna do Estado emissor. ${ }^{182}$ No entanto, a lei do pagamento da obrigação era a lei francesa, dada a soberania monetária da França sobre os

179 "Any contract which is not a contract between States in their capacity as subjects of international law is based on the municipal law of some country." (CPJI, Case Concerning the Payment in Gold of the Serbian Federal Loans Issued in France, série A, n. 14, 1929, p. 41).

${ }^{180}$ É prudente relembrar que, na época de julgamento, não se distinguiam com clareza os termos loans e bonds, razão pela qual o caso dos empréstimos sérvios e brasileiros poderiam ser hoje renomeados, com mais precisão, como o caso dos títulos públicos sérvios e brasileiros.

181 BROWNLIE, I. Principles of Public International Law. 7. ed. Nova Iorque: Oxford University Press, 2010, p. 36.

182 CPJI, Case Concerning the Payment in Gold of the Brazilian Federal Loans Issued in France, série A, n. 15, 1929, p. 121. 
francos de sua denominação. Com isto, diferentes partes da obrigação seriam regidas também por ordens jurídico-territoriais distintas. ${ }^{183}$ Assim, as cláusulas monetárias de pagamento da dívida pública teriam a interpretação determinada pelo direito estrangeiro, no caso o francês.

Em aplicação do princípio pacta sunt servanda, reconhecido pela jurisprudência da Corte de Cassação francesa, a Corte Permanente decidiu que as cláusulas-ouro, que protegiam os credores franceses contra a desvalorização da unidade de pagamento, receberam o expresso consentimento de todas as partes. Ainda, portanto, que a dívida doméstica francesa não pudesse contar com semelhante lastro monetário, nada obstava sua adoção, pela via contratual, no âmbito externo. ${ }^{184} \mathrm{Os}$ casos dos empréstimos sérvios e brasileiros apontam para uma limitação ao poder do Estado devedor de definir a moeda em que se realizará o pagamento de suas obrigaçôes externas. Reconhecida a validade das cláusulas-ouro nos contratos internacionais pela lei do Estado emissor da moeda, a preservação do valor das obrigações prevalece sobre a inscrição nominal do montante devido. $\mathrm{O}$ curso forçado da moeda doméstica, portanto, era regra que se observaria em contratos internos, mas que não se estenderia de imediato às obrigações internacionais.

Outro caso complementaria o tema. O caso dos empréstimos noruegueses, de 1957, apresentado perante a Corte Internacional de Justiça (CIJ) traz elementos que atestam formas de limitação, por contratos internacionais, da decisão do Estado sobre os meios de pagamentos de suas obrigaçôes. Novamente, a disputa se deu com investidores franceses que haviam comprado títulos públicos noruegueses durante o período de 1925 a 1955. Como nos casos dos empréstimos e sérvios, o governo norueguês havia firmado contratos que contavam com cláusulas-ouro. A legislação norueguesa permitia, no entanto, que pagamentos em coroas expressos em ouro fossem satisfeitos em papel pelo valor nominal, e aos credores se oferecia o

${ }^{183}$ Como ficou dito no caso sérvio, "it is quite possible that the same law may not govern all aspects of the obligation. The distinction which seems indicated for the purposes of this case is more particularly that between the substance of the debt and certain methods of payment thereof" (CPJI, Case Concerning the Payment in Gold of the Serbian Federal Loans Issued in France, série A, n. 14, 1929, p. 41).

184 Por ser potencialmente discriminatório, este é um aspecto da decisão criticado em WÄLDE, T. The Serbian Loans Case: a Precedent for Investment Treaty Protection of Foreign Debt? In: WEILER, T. (coord.). International Investment Law and Arbitration: Leading Cases from the ICSID, NAFTA, Bilateral Treaties and Customary International Law. Londres: Cameron May, 2005, p. 399. Crítica semelhante pode ser lida em WAIBEL, M. Sovereign Defaults before International Courts and Tribunals. Cambridge: Cambridge University Press, 2011, p. 64. 
direito de adiar os pagamentos caso discordassem da solução por notas de coroas. A extinção da conversibilidade de pagamentos do Estado ocorreu por leis internas da Noruega em 1909, 1920 e, finalmente, em 1931. ${ }^{185}$

A base jurídica da disputa é distinta daquela elaborada nos dois casos anteriores. Isto porque, em sua objeção às alegaçôes do governo francês, a Noruega aduzia a existência de uma reserva feita pela sua contraparte à competência da Corte. A reserva se fundaria na declaração do governo francês de que reconheceria, limitadamente, a competência da Corte apenas sobre as matérias que não estivessem estritamente sob sua jurisdição interna. Por outra forma, o consentimento para o exercício daquela jurisdição se daria exclusivamente quanto a assuntos que se reconhecessem como internacionais. ${ }^{186}$ A declaração norueguesa, por sua vez, era menos restritiva sobre a abrangência dos poderes jurisdicionais da CIJ, impondo, como condição básica, apenas a reciprocidade. ${ }^{187}$ A Noruega não apresentava, assim, a mesma reserva de competência (self-judging reservation) que havia sido colocada pela França.

A alegação francesa de que a emissão dos títulos pela norueguesa em território externo seria matéria internacional, pois vigia um tratado entre as partes a respeito de disputas sobre a dívida pública. Tratava-se da Convenção de Haia de 1907, que havia proscrito o emprego da força para a recuperação de empréstimos públicos internacionais. Foram mencionados, também, inúmeros casos financeiros resolvidos por comissões mistas internacionais, e se recorreu ao argumento de que, sem negociações, não seria lícito que uma decisão unilateral de um Estado tivesse efeitos extraterritoriais sobre direitos contratuais de não residentes. O governo norueguês afirmava, a seu turno, a submissão do tema da unidade monetária de pagamento da dívida pública a sua soberania interna e, para o que interessa particularmente ao caso, pretendeu invocar a reserva de competência francesa em seu favor, em razão da exigência de reciprocidade no reconhecimento da competência da corte internacional.

185 CIJ, Certain Norwegian Loans Case, França v. Noruega, 1957, p. 9 e seguintes.

186 CIJ, Certain Norwegian Loans Case, França v. Noruega, 1957, p. 16. Segundo a declaração de consentimento francesa quanto à jurisdição da Corte Internacional de Justiça, ele não se estenderia a "differences relating to matters which are essentially within the national jurisdiction as understood by the Government of the French Republic".

187 CIJ, Certain Norwegian Loans Case, França v. Noruega, 1957, p. 16. “(...) the Norwegian Government that Norway recognizes as compulsory ipso facto and without special agreement, in relation to any other State accepting the same obligation, that is to say, on condition of reciprocity, the jurisdiction of the International Court of Justice in conformity with Article 36, paragraph 2, of the Statute of the Court (...)". 
Quanto ao mérito, a Convenção de Haia não criava um dever jurídico de submissão de controvérsias sobre a dívida pública à arbitragem internacional, pois o propósito do documento, segundo a decisão, consistia apenas em limitar a possibilidade do uso da força antes que se tivessem iniciado procedimentos negociais e arbitrais. ${ }^{188}$ A Convenção de Haia não obstava, portanto, a invocação norueguesa da reserva da declaração do Estado francês, cuja procedência foi reconhecida pela Corte. Com o que a CIJ afastou a própria competência do caso, por entender que, pela aplicação recíproca da reserva francesa, os títulos públicos noruegueses se submetiam a sua exclusiva jurisdição interna.

Para o desenvolvimento do direito internacional aplicável à dívida pública, é de lamentar que as questôes de mérito nunca tenham sido enfrentadas pela Corte Internacional de Justiça. Algumas destas questôes podem ser vislumbradas nos votos dissidentes dos juízes Read e Lauterpacht. O primeiro havia observado a existência de tratamento diferenciado dos credores dinamarqueses e suecos, ainda que o governo norueguês alegasse também ter favorecido os credores franceses em determinadas ocasiōes e que não havia uma regra jurídica internacional que o obrigasse ao tratamento equitativo. Isto mostra a dificuldade de estabelecer um princípio jurídico de tratamento não favorecido entre credores externos da dívida pública. A eleição discriminatória de moedas de pagamento seria justificável em circunstâncias de necessidade econômica, afirmava a Noruega. Independentemente da procedência do argumento, a dissidência do juiz Read é marcada por uma ideia forte: a de que a equidade no tratamento entre diferentes classes de credores é uma matéria atinente ao direito internacional, e não apenas ao direito interno. ${ }^{189}$ Em antecipação a uma discussão que se estabeleceria posteriormente, o voto divergente mencionava, obiter dictum, alguns parâmetros jurídicos para o default de Estados: se as circunstâncias econômicas justificariam

188 CIJ, Certain Norwegian Loans Case, França v. Noruega, 1957, p. 19. "The purpose of the [Hague] Convention in question is that indicated in its title, that is to say, 'the Limitation of Employment of Force for the Recovery of Contract Debts'. The aim of this Convention is not to introduce compulsory arbitration in the limited field to which it relates. The only obligation imposed by the Convention is that an intervening Power must not have recourse to force before it has tried arbitration".

189 CIJ, Certain Norwegian Loans Case, França v. Noruega, Opinião Dissidente do Juiz Read, 1957, p. 91. "It is, of course, impossible for me at the present stage to indicate my views as to whether France or Norway is right, whether the matter is considered from the point of view of discrimination or extraterritoriality. On the other hand, I find insuperable difficulty in reaching the conclusion that a case involving these issues can be treated as being solely one of national law (...).” 
alguma forma de inexecução da dívida pública, explícita ou pela via de reforma monetária, a elas deveria corresponder um dever jurídico de igual tratamento entre os credores. ${ }^{190}$

Em sentido semelhante foi a dissidência do juiz Lauterpacht, que reconhecia a incidência de duas ordens normativas sobre os empréstimos externos: o direito interno do local de emissão, mas também o direito internacional, que serviria de parâmetro para caracterizar eventuais violações de direitos contratualmente assegurados. O princípio afirmado nos casos dos empréstimos sérvios e brasileiros de que a emissão de títulos públicos no exterior deveria se submeter ao direito interno de algum Estado não significaria que ficasse assim sujeito com exclusividade, como se o direito interno fosse matéria completamente alheia e incompatível com o direito internacional. Notava, então, que "a legislação nacional - incluindo a legislação monetária - pode ser contrária, em sua intenção ou em seus efeitos, às obrigações internacionais do Estado. A questão da conformidade da legislação nacional ao direito internacional é uma matéria do direito internacional". ${ }^{191}$ Sobretudo por lidar com direitos de propriedade de estrangeiros, a matéria referente ao pagamento das obrigações externas sem atenção a cláusulas de preservação de valor da moeda deveria obedecer as normas de direito internacional referentes ao tratamento equitativo dos credores. Ainda, portanto, que os tribunais noruegueses tenham competência para aplicar o direito interno a eventuais disputas, a responsabilidade internacional do Estado não estaria afastada sem mais. Aponta, ainda, que as decisões dos casos sérvio e brasileiro não haviam sido uniformemente reproduzidas em tribunais nacionais, alguns dos quais aceitavam o curso forçado para contratos internacionais, e outros que, mais de acordo com a decisão da CPJI, aceitavam as vontades expressas no contrato de manutenção do valor dos pagamentos em função de um lastro cambial. ${ }^{192} \mathrm{~A}$ fragmentação da disciplina jurídica da dívida pública já se mostrava, aí, evidente.

190 CIJ, Certain Norwegian Loans Case, França v. Noruega, Opinião Dissidente do Juiz Read, 1957, p. 79. "The argument was that Norway, in special circumstances, was justified in suspending gold payments, or the payment of gold equivalents. That justification necessarily involved a correlative obligation to give equal treatment to all creditors involved."

191 CIJ, Certain Norwegian Loans Case, França v. Noruega, Opinião Dissidente do Juiz Lauterpacht, 1957, p. 32, tradução livre. No original, "[n] ational legislation - including currency legislation - may be contrary, in its intention or effects, to the international obligations of the State. The question of conformity of national legislation with international law is a matter of international law".

192 Cf. CIJ, Certain Norwegian Loans Case, França v. Noruega, Opinião Dissidente do Juiz Lauterpacht, p. 35. 
De um lado, os casos dos empréstimos sérvios e brasileiros foram julgados por uma Corte que encontrou poucas dificuldades para afirmar sua competência, considerada a disposição do governo francês para exercer a proteção diplomática de seus nacionais. A decisão de que os contratos entre Estados e particulares estariam necessariamente sob a disciplina de algum direito interno pareceria indicar, como depois seria colocado no caso dos empréstimos noruegueses, que este poder seria exclusivo. Esta última disputa, no entanto, não chegou a ser decidida no mérito, razão pela qual não se pode afirmar que haja precedentes internacionais sobre a incidência isolada de normas de direito interno sobre as obrigações financeiras externas do Estado, quer sejam elas sobre o conteúdo da obrigação ou sobre a disciplina jurídica dos meios do pagamento. Há elementos de direito internacional, como se apreende dos votos dissidentes desse último caso, que se aplicam a questões como o tratamento discriminatório entre credores residentes e não residentes, entre credores nacionais e estrangeiros e o direito de propriedade de estrangeiros. O poder de um Estado reduzir os pagamentos de sua dívida pública por meio de alterações na gestão da moeda leva em conta, portanto, não apenas o exercício das próprias competências monetárias, mas também o cumprimento de cláusulas internacionais de preservação do valor da moeda e normas de direito internacional aplicáveis à proteção dos direitos dos credores.

Uma última observação sobre estes casos. O sistema monetário internacional na época de julgamento dos casos sérvio e brasileiro, em 1927, seria irreconhecível quando a Corte de Justiça Internacional foi chamada a decidir o conflito entre França e Noruega. Em 1957, o padrão-ouro já se mostrava como uma reminiscência histórica, e isso talvez ajude a explicar o estranhamento que causariam, em uma nova ordem econômica de moedas flutuantes, acordos que previssem a vinculação de uma unidade monetária com curso forçado ao ouro. Sob o impacto da conjuntura econômica do pós-segunda guerra, o risco de uma desvalorização cambial é um elemento integrante dos contratos internacionais. Ao contrário do que afirma Waibel, no entanto, disso não se pode concluir que não existe um dever geral de tratar aos diferentes grupos de credores de forma equitativa. ${ }^{193}$ Embora não seja possível assegurar que os sacrifícios impostos aos diversos grupos de credores sejam absolutamente idênticos, um princípio internacional de tratamento não discriminatório pode significar que o Estado tem ao menos o dever jurídico de promover

193 O autor afirma que não chega a constituir uma discriminação que um grupo de credores receba, efetivamente, um pagamento menor do que outro grupo de credores. Cf. WAIBEL, M. Sovereign Defaults before International Courts and Tribunals. Cambridge: Cambridge University Press, 2011, p. 87. 
negociações que assegurem ajustes mais equânimes. Neste caso, as instituições internacionais, como o local de condução destas negociações e de coordenação de interesses divergentes entre Estados e credores, assim como entre as classes de credores entre si, são indispensáveis para a condução ordenada dos procedimentos de negociação.

Cabe, por fim, lembrar que há limitações mais concretas, no âmbito do FMI, sobre o poder regulatório do Estado sobre a moeda. Sob o Acordo Constitutivo do Fundo, reconhece-se o princípio da soberania monetária dos Estados com algumas limitações. Se, por um lado, o país-membro tem o poder de determinar o valor da própria moeda, atrelando-o a alguma unidade de valor qualquer para dar garantias de preservação de seu valor, o que se poderia fazer tendo os Direitos Especiais de Saque como lastro, o ouro não pode ser adotado como denominador de referência. ${ }^{194}$ As taxas de câmbio tampouco podem ser manipuladas para distorcer o balanço de pagamentos ${ }^{195}$ e vedam-se, sem a autorização do Fundo, as práticas plurimonetárias, pelas quais se estabelecem taxas de conversão diversificadas, não unitárias e, por isso mesmo, potencialmente discriminatórias. ${ }^{196}$

\subsubsection{Modificações subjetivas: sucessão de Estados}

As situações potencialmente conflitivas entre o Estado e os credores da dívida pública nem sempre se originam de modificações das condições de pagamento, sejam elas explícitas, por meio de reestruturações formais, ou implícitas, pelo caminho das alterações monetárias. Em vez das modificações objetivas, o motivo de determinadas colisões de interesses são novações subjetivas das obrigações, isto é, a alteração de uma de suas partes. Não é o caso de se tratar das cessões de títulos

194 Art. 4, Seção 2, alínea "a”: "[e]ach member shall notify the Fund, within thirty days after the date of the second amendment of this Agreement, of the exchange arrangements it intends to apply in fulfillment of its obligations under Section 1 of this Article, and shall notify the Fund promptly of any changes in its exchange arrangements." (FMI. Articles of Agreement of the International Monetary Fund (1944). Washington, D.C.: FMI, 2011, p. 6).

195 Art. 4, Seção 1, número "iii”: “(...) each member shall (...)avoid manipulating exchange rates or the international monetary system in order to prevent effective balance of payments adjustment or to gain an unfair competitive advantage over other members" (FMI. Articles of Agreement of the International Monetary Fund (1944). Washington, D.C.: FMI, 2011, p. 5-6).

196 Art. 8, Seção 3: "“[n] o member shall engage in, or permit any of its fiscal agencies referred to in Article V, Section 1 to engage in, any discriminatory currency arrangements or multiple currency practices, whether within or outside margins under Article IV or prescribed by or under Schedule C, except as authorized under this Agreement or approved by the Fund." (FMI. Articles of Agreement of the International Monetary Fund (1944). Washington, D.C.: FMI, 2011, p. 23). 
públicos negociáveis no mercado financeiro que os transfiram de uns para outros credores, hipótese que configuraria a modificação subjetiva do polo ativo da obrigação. A análise da validade destas operações variaria conforme a disciplina jurídica específica de cada espécie de título emitido por cada Estado nacional - um estudo que, além de monumentalmente abrangente, seria ainda infrutífero para o objetivo aqui considerado. Isto porque as características objetivas da obrigação seriam mantidas e, se um determinado papel da dívida pública é alienável a terceiros pelo subscritor (sendo, portanto, negociável), este é um elemento essencial da obrigação já previsto desde a sua constituição. $\mathrm{O}$ caso não trataria nenhuma contribuição, portanto, para as hipóteses de inexecução da dívida pública que não pudessem ser resolvidas pelos dispositivos contratuais de cada título público.

O mesmo não se passa com as alterações subjetivas do polo passivo da obrigação financeira, isto é, com a transmissão da obrigação de um Estado para outro Estado sucessor. Neste caso, a disciplina é mais imprecisa. Embora a suspensão do pagamento não seja um dado inescapável do problema, pois a transmissão pode se operar sem conflitividade, certos componentes jurídicos do direito internacional levaram alguns Estados a não reconhecer a validade da dívida pública assumida por seus antecessores, ou ainda a tratar sob critérios muito distintos a repartição das obrigações na hipótese de divisão territorial. Também nestes casos, os elementos normativos, e não apenas as considerações de índole política e econômica, estabelecem a conformação complexa do fenômeno da dívida pública. Sob a perspectiva dos credores, é matéria crucial que se saiba, em caso de sucessão de Estados, qual ente passa a ser seu devedor, e em que medida os termos originais da obrigação serão preservados de futuras alteraçōes. Esses elementos propriamente jurídicos foram concretamente enfrentados em casos emblemáticos.

O primeiro deles diz respeito à distribuição da dívida do antigo Império Otomano, disciplinada pelo Tratado de Paz de Lausanne, de 24 de julho de 1923, pelo qual se reconhecia o Estado da Turquia. Ao lado de outras provisóes, o tratado previa a repartição dos encargos da dívida pública entre dois grupos de Estados: aqueles que haviam se desmembrado do território otomano em razão das guerras balcânicas de 1912 e 1913, e aqueles separados após a primeira guerra mundial. Assim, aos novos Estados do primeiro grupo seria atribuída uma dada parte dos compromissos financeiros prévios existentes até os conflitos dos Bálcãs, ao passo que as obrigações restantes (isto é, aquelas que haviam ficado com a Turquia, continuadora do Estado otomano, após a primeira distribuição) seriam partilhadas entre os novos Estados surgidos após a sua dissolução total. Ambos os grupos assumiriam a responsabilidade pelo débito de acordo com a proporção de sua contribuição para as receitas totais do Império em dois exercícios fiscais (1910 a 1911 e 
1911 a 1912). Na distribuição dos encargos para o segundo grupo, no entanto, as dívidas que haviam sido designadas aos Estados balcânicos deveriam ser excluídas do total das receitas turcas. ${ }^{197}$ As estipulações do tratado, ou seja, o valor da dívida pública que seria distribuída aos novos Estados, seriam calculadas pelo conselho da já mencionada Ottoman Public Debt Administration e eventuais disputas seriam resolvidas por um árbitro indicado pela Liga das Nações. ${ }^{198}$

As disputas a serem resolvidas pelo procedimento arbitral de fato ocorreram, pois parte significativa dos Estados contestou a repartição liquidada pela OPDA, apontando-se para o caso o árbitro Eugène Borel, professor de direito internacional na universidade de Genebra. Recorreram da decisão do conselho da administração da dívida otomana, em primeiro lugar, a Grécia, em 1924, seguida da própria Turquia, que alegava ter o tratado de paz promovido tratamentos desiguais ao não prever deduções nas receitas de outros territórios. Outros Estados sucessores, ainda, apelaram à solução pela via arbitral, juntando-se aos anteriores. Assim o Iraque, a Palestina e a Transjordânia, representados pelo Reino Unido, e Síria e Líbano, representados pela França, além da Bulgária. ${ }^{199}$

O árbitro estabeleceu que a distribuição das dívidas públicas entre os sucessores não se daria a partir de princípios gerais de direito internacional, mas de acordo com os termos do tratado que a regule. $\mathrm{O}$ Tratado de Lausanne dizia que as quotas da dívida otomana seriam repartidas de modo que cada novo Estado ficasse com a mesma proporção que aquela representada por sua participação nas receitas totais do antigo império, o que se calcularia com base nos exercícios já mencionados. Muitos Estados afirmavam ser esse critério injusto, pois ativos haviam sido transferidos de um território a outro. Alguns postos alfandegários haviam sido deslocados, e terras produtivas haviam sido perdidas por alguns países em favor de outros. A distribuição exclusivamente proporcional desconsiderava estas variaçôes nas capacidades econômicas ocorridas desde a dissolução otomana. Outras particularidades, como a diferença no local de pagamento e no local de depósito dos tributos arrecadados, não foram contempladas pelo tratado. Princípios gerais de tratamento

197 Estas são as previsōes do art. 51, números I e II, do documento. Cf. Tratado de Paz com a Turquia, 24/7/1923. Disponível em: <http://sam.baskent.edu.tr/belge/Lausanne_ENG. pdf>. Acesso em: 16/9/2015.

198 Art. 47 do Tratado de Paz com a Turquia, 24/6/1923. Disponível em: <http://sam.baskent. edu.tr/belge/Lausanne_ENG.pdf>. Acesso em: 16/9/2015.

199 Outros detalhes factuais do caso estão em WYNNE, W. State Insolvency and Foreign Bondholders: Selected Case Histories of Governmental Foreign Bond Defaults and Debt Readjustments. Washington, DC: Beard Books, vol. II, p. 490 e seguintes. 
equitativo, preocupados com alguma forma de justiça substancial na repartição dos encargos financeiros, não estariam aptos, porém, a revogar disposiçõos expressas do tratado regulador da sucessão. ${ }^{200}$ Outros aspectos precisaram ser ainda enfrentados, pois a Bulgária havia cedido territórios à Grécia, em 1924, mas estes territórios haviam sido militarmente ocupados pelos gregos já em 1918. O governo búlgaro afirmava, então, não ser responsável pelas obrigações financeiras das regiōes cedidas desde a data da ocupação militar, enquanto o governo grego defendia sua responsabilidade pelos débitos apenas a partir da formalização da cessão - disputa decidida em favor da data de rendição da Bulgária, em 1919, celebrada pelo Tratado de Neuilly. Inúmeras questôes intrincadas foram ainda trazidas à tona, as quais dispensam apresentação detalhada. É suficiente mencionar que a arbitragem foi chamada a se pronunciar sobre situações bastante minuciosas, tais como a legitimidade para a arrecadação das receitas de determinadas ferrovias, a disposição dos fundos pessoais de sultôes depostos e os direitos de passagem pagos por barcos a vapor nos rios Tigre e Eufrates. Todas questóes da natureza eminentemente técnica, ${ }^{201}$ as quais, contudo, exigiam a demonstração da existência de certos benefícios e encargos totais que não haviam sido previstos no tratado.

A despeito do elevado número de questôes complexas, a simplicidade do critério de decisão adotado chegou a ser elogiada. Assim, "nunca uma decisão arbitral mais simples foi urdida para a solução de problemas mais intrincados e técnicos. (...) Ela pode servir bem como um modelo para outras arbitragens similares, em que pesados procedimentos e atrasos desnecessários deveriam ser evitados”. ${ }^{202} \mathrm{Nem}$ mesmo o fato da Bulgária não ser signatária do Tratado de Lausanne impediu uma rápida solução vinculante para todos os Estados sucessores - algo que aponta para uma contrariedade com o princípio costumeiro de direito internacional de que os

${ }^{200}$ Detalhes da decisão e comentários contemporâneos ao caso podem ser encontrados em BROWN, P. M. Ottoman Public Debt Administration. The American Journal of International Law, Washington, D.C., vol. 20, n. 1, jan. 1926, p. 135-9. Para literatura mais recente, ver BANKEN, R. Die Verträge Von Sèvres 1920 und Lausanne 1923: eine völkerrechtliche Untersuchung zur Beendigung des ersten Weltkrieges und zur Auflösung der sogenannten "Orientalischen Frage" durch die Friedensverträge zwischen den aliierten Mächten und der Türkei. Berlim: LiT, 2014, p. 468 e seguintes.

201 BROWN, P. M. Ottoman Public Debt Administration. The American Journal of International Law, Washington, D.C., vol. 20, n. 1, jan. 1926, p. 138 e seguintes.

${ }^{202}$ Idem, p. 136, tradução livre. No original, “[n] ever was a simpler device contrived for the solution of more intricate, technical problems. Never was an arbitral decision characterized by greater clarity and good sense. The whole proceeding from start to finish was of the finest simplicity. It may well serve as a model for other similar arbitrations where ponderous procedure and needless delay should be avoided." 
tratados são vinculantes apenas para as partes. ${ }^{203} \mathrm{~A}$ Turquia, por sua vez, foi entendida como continuação do Estado predecessor, razão pela qual se lhe atribuíram as dívidas residuais, não distribuídas a outros Estados. ${ }^{204}$

Algumas importantes conclusōes podem ser extraídas da notavelmente simples decisão arbitral. A primeira delas é que o argumento recorrente de que haveria algum direito a tratamento justo e equitativo na repartição da dívida pública em caso de sucessão de Estados não é uma afirmaçãao evidente. As tentativas de restringir o âmbito de aplicação do princípio pacta sunt servanda por um princípio jurídico mais amplo de equidade substancial não tiveram acolhida no caso da sucessão da dívida otomana, com uma larga margem de indeterminação do direito internacional a respeito. Neste ponto, é conveniente, a partir desta afirmação, deixar suspenso o juízo sobre o caso da dívida otomana, em que se refletiu sobre a existência de princípio gerais de direito sobre a continuidade da dívida pública em casos de mudança de soberania, para apontar o interesse da discussão para a doutrina do direito internacional.

As principais tomadas de posição a esse respeito se dividem a partir do questionamento de regras gerais vinculantes do direito internacional sobre a sucessão de Estados em matéria de dívida pública. Em analogia ao direito interno dos Estados, e amplamente baseada em pilares históricos herdados do direito romano, uma primeira categoria doutrinária poderia ser identificada na opinião de que haveria uma sucessão universal nas obrigações do Estado predecessor, em relação ao qual o Estado sucessor se comportaria como herdeiro. ${ }^{205}$ Segundo esta construção, por assim dizer, civilista, as obrigaçóes dos antecessores se transmitem do de cujus aos sucessores quer se trate de uma pessoa privada ou de um ente dotado de soberania. A ideia subjacente é a de uma imanente continuidade tanto dos benefícios como dos encargos do ente sucedido, a partir da qual se constrói a doutrina da universalidade da sucessão no patrimônio público. Em seguida a esta opinião bastante influente até o século XIX, desenvolveram-se algumas vertentes que enxergaram na continuidade da população o fundamento para a permanência das obrigações do Estado

203 Cf. WAIBEL, M. Sovereign Defaults before International Courts and Tribunals. Cambridge: Cambridge University Press, 2011, bem como o art. 11 da Convenção de Viena sobre o Direito dos Tratados.

${ }^{204}$ MARTHA, R. The Financial Obligation in International Law. Oxford: Oxford University Press, 2015, p. 582.

205 Para a recuperação da história do direito internacional a respeito, ver O'CONNELL, D. P. State Succession in Municipal Law and International Law. 2. ed. Cambridge: Cambridge University Press, 1967, p. 28 e seguintes. 
sucedido, pois não teria havido alterações na identidade material do Estado (o povo e outros elementos orgânicos), e sim apenas em seus elementos formais. Nesta situação, se poderia falar de uma sucessão de direito público e de uma sucessão quase-universal, pela qual o Estado sucessor, como ente dotado de personalidade unitária e indivisível, gozaria do direito formal de recusar as obrigaçōes advindas do predecessor. O exercício desse direito comprometeria, porém, a estabilidade das relações jurídicas, razão pela qual a comunidade internacional exigiria a necessária proteção das relações assumidas anteriormente à sucessão, que assumiria um caráter sócio jurídico. ${ }^{206}$

A dificuldade de concepções teóricas fundadas na ideia de que a sucessão nas obrigaçôes constituiria um princípio vinculante do direito internacional, com base em noções apriorísticas de sucessão universal ou de continuidade do substrato social, ainda que possam vir a atingir o efeito de estabilizar as relações jurídicas, não são uma obviedade quando tomadas em consideração as práticas mais correntes em matéria de dívida pública. Tomem-se dois casos, a anexação do território do Texas pelos Estados Unidos, em 1844, e de territórios coloniais pelo Império Britânico. Ambos exibem características bastante distintas da doutrina de uma vinculação do Estado sucessor às obrigações anteriormente assumidas, e estão na base das influentes posições americana e britânica a esse respeito.

A dívida pública da República texana havia sido em grande parte garantida por receitas e terras daquele Estado, e foram parcialmente assumidas pelo governo federal dos Estados Unidos, conforme o tratado de união de 1844. O tratado, porém, foi rejeitado pelo Senado, que formalizou posteriormente a união por meio de uma resolução de 1850 que não tratava do tema da dívida pública. Esta lacuna foi responsável por uma grande margem de insegurança para os credores da dívida texana. Pouco tempo depois, credores britânicos reclamaram o pagamento dos débitos da República do Texas perante comissão arbitral mista entre os Estados Unidos e a Inglaterra, que havia sido formada em 1853 para a solução de disputas internacionais entre cidadãos de um Estado e o governo de outro. A despeito, porém, da assunção anterior da dívida do território anexado e da doutrina dominante no período, o governo dos Estados Unidos alegou que o pedido se dirigia propriamente contra o estado do Texas, e não contra o ente federal. $\mathrm{O}$ argumento foi aceito pela comissão, ainda que posteriormente revertido por lei aprovada pelo

206 Ver também O’CONNELL, D. P. Recent Problems of State Succession in Relation to New States. Recueil des Cours, Leiden, vol. 130, n. 2, 1970, p. 111. Além dele, BERNARDEZ, S. T. Succession of States. In: BEDJAOUI, M. (Coord.). International Law: Achievements and Prospects. Dordrecht: Martinus Nijhoff, 1991, p. 381. 
Congresso americano que previa o pagamento pro rata aos detentores de títulos texanos. ${ }^{207} \mathrm{~A}$ indefinição do governo norte-americano, neste caso, prolongou por anos as incertezas sobre a continuidade das obrigaçôes financeiras do Texas e, ainda que o parlamento daquele país tenha revertido a decisão de não pagar, em muitos casos os valores efetivamente desembolsados foram inferiores àquele previsto nos títulos públicos atingidos. Não se pode dizer, portanto, ter havido certeza jurídica quanto à obrigação dos Estados Unidos de assumir a dívida de um território em decorrência de transmissão da soberania. Esse país seria novamente às voltas com o mesmo problema quando, ao fim da guerra com a Espanha em 1898, deveria ser decidida a questão da dívida dos territórios cedidos e anexados de Cuba, Porto Rico, outras ilhas caribenhas e as Filipinas. As negociações não foram tranquilas quanto à transferência das obrigaçōes, o que levaria E. Feilchenfeld, em análise do caso no monumental estudo sobre o tema da sucessão em matéria de dívida pública, a afirmar que "nem duzentos anos de desenvolvimento dos costumes, nem as várias abstrações e teorias dos escritores criaram regras reconhecidas de direito internacional sobre o tratamento das dívidas em casos de cessão". ${ }^{208} \mathrm{Nem}$ mesmo argumentos ligados a uma ideia mais abstrata de justiça com os credores da dívida cubana deram sinais mais claros à resolução de uma disputa marcada pela aplicação de critérios mais políticos e menos jurídicos.

O caso da Grã-Bretanha ilustra o desenvolvimento de determinadas práticas que tinham o objetivo explícito de evitar o lançamento de precedentes sobre a vinculação às obrigaçôes anteriormente assumidas pelo precedessor. $\mathrm{O}$ exemplo mais significativo diz respeito à anexação das repúblicas bôeres do Transvaal e do Estado Livre de Orange, que atualmente constituem parte da África do Sul, após a conclusão das guerras dos bôeres, em 1902. A política externa britânica consolidou a prática já anteriormente observada de que a assunção das dívidas anteriores pelo Estado sucessor é um ato ex gratia, e não ex lege. ${ }^{209}$ A obrigação de absorver as

207 Cf. HOEFLICH, M. Through a Glass, Darkly: Reflections upon the History of the International Law of Public Debt in Connection with State Succession. University of Illinois Law Review, Champaign, vol. 39, n. 1, 1982, p. 49 e seguintes.

${ }^{208}$ Public Debts and State Succession. Nova Iorque: McMillan, 1931, p. 329-230, tradução livre. No original, “[ $t]$ hat neither two hundrer years' development of usage, nor the various abstractions and theories of writers had created recognized rules of international Law on the treatment of debts in case of cession, was shown even more clearly in the peace negotiations which followed the Spanish-American War of 1898".

${ }^{209}$ HOEFLICH, M. Through a Glass, Darkly: Reflections upon the History of the International Law of Public Debt in Connection with State Succession. University of Illinois Law Review, Champaign, vol. 39, n. 1, 1982, p. 56. Para os casos anteriores de Fiji e Burma Superior, ver 
obrigações dos territórios conquistados contrastava, então, com a sucessão nos ativos; isto é, o enriquecimento com a conquista se separava do reconhecimento dos gravames que ela também acarretava. Sobre este pano de fundo se defendia a tese de que a continuação na parcela positiva do patrimônio não se estendia, automaticamente, à substituição subjetiva da posição de devedor nos empréstimos públicos. O estudo histórico de Hoeflich, que teve acesso a documentos que registram debates internos no ministério das relações exteriores britânico, expõe que este tema tinha um direcionamento político claro, e fazia parte da estratégia externa a negação de qualquer princípio jurídico vinculante dirigido à transferência obrigatória da dívida pública em caso de sucessão. A eventual assunção dos débitos seria um ato voluntário, a ser ajustado conforme os interesses em negociação. Outra questão a ser discutida seria a possibilidade de ocorrer uma modificação objetiva das obrigações financeiras; se, entre as hipóteses do tudo ou do nada, negando ou assumindo os débitos em sua totalidade, seria possível a solução intermediária de alterar os valores devidos e alongar os prazos de pagamento. ${ }^{210}$ É difícil avaliar, nestes debates, se havia alguma convicção jurídica paralela às considerações estratégicas. A posição final do governo do Reino Unido foi a de pagar cerca de $10 \%$ do valor de face dos papeis bôeres, com exceção daqueles emitidos para financiar as operações militares contra os britânicos. Neste sentido, é uma decisão semelhante à dos Estados Unidos em relação ao Texas, em que, por decisão unilateral e alegadamente não vinculada, houve-se por bem reconhecer parte da dívida pública da república conquistada, convertendo-a, no entanto, em obrigações de menor valor.

O cotejo histórico com outros casos mais recentes exibe as idas e vindas da prática dos Estados em relação a este tema. Estas idiossincrasias permanecem ao longo do tempo, o que não permite vislumbrar com clareza os critérios de distribuição dos encargos da dívida pública entre os Estados (como se anteviu na sucessão do império otomano), e tampouco obter alguma convicção de juridicidade sobre o dever de reembolso integral aos credores do Estado predecessor proveniente de prática reiterada nesse sentido. Quanto aos critérios de repartição dos encargos, foram e ainda são adotados os mais variados deles. A divisão de Estados maiores significou a distribuição da dívida de acordo com a população (Grande Colômbia, em 1831, e República Federal da América Central, em 1841), ou as receitas fiscais (Império

FEILCHENFELD, E. Public Debts and State Succession. Nova Iorque: McMillan, 1931, p. 287 e seguintes.

210 HOEFLICH, M. Through a Glass, Darkly: Reflections upon the History of the International Law of Public Debt in Connection with State Succession. University of Illinois Law Review, Champaign, vol. 39, n. 1, 1982, p. 58. 
Otomano e Austro-Húngaro), ou o Produto Interno Bruto - PIB (Federação Centro-Africana, em 1963), ou a população em relação ao PIB (Tchecoslováquia, em 1993). Na dissolução da Iugoslávia, a divisão da dívida pública se fez a partir de procedimentos orientados pelo FMI que procuraram assegurar uma repartição equitativa dos encargos a partir das potencialidades econômicas dos novos estados independentes. Em outras situações, ainda, não se promoveu divisão alguma. Quando da secessão de Bangladesh, em 1971, o Paquistão concordou em permanecer com a totalidade da dívida pública, sem atribuí-la parcialmente ao novo país. ${ }^{211}$ A espera pela definição de um critério de repartição traz determinadas incertezas aos credores as quais contribuem para uma dada percepção do risco. Avaliou-se, aqui, a anexação do Texas e de territórios caribenhos, para os quais se adotaram determinadas linhas de atuação responsáveis pela significativa redução dos preços dos títulos dos Estados Unidos nos anos seguintes. ${ }^{212} \mathrm{E}$, durante a unificação da Itália, a possibilidade de conversão das obrigações dos territórios que se uniam em títulos do novo reino, em 1861, não foi bem recebida por investidores estrangeiros, que temiam, assim, perder as condiçóes de analisar separadamente o risco de cada entidade territorial. ${ }^{213}$

Disposições mais claras foram previstas na Convenção de Viena sobre a Sucessão de Estados em matéria de Bens, Arquivos e Dívidas do Estado, de 1983. Nela se antevê a afirmação de um princípio da distribuição equitativa da dívida pública. $\mathrm{O}$ artigo $37 \mathrm{da}$ Convenção, além de prever o respeito à vontade dos Estados manifestada em acordo que discipline a divisão dos encargos, afirma que, na ausência desse acordo, a dívida do Estado predecessor passará ao sucessor em proporção equitativa (equitable proportion). ${ }^{214}$ A convenção, no entanto, nunca entrou em vigor em razão da ausência de número suficiente de ratificações. A afirmação de regras sobre a sucessão na dívida pública encontra dificuldades para superar algo que vá além do princípio pacta sunt servanda, o qual, em razão da ausência de

211 OOSTERLINCK, K. Sovereign Debt Defaults: Insights from History. Oxford Review of Economic Policy, Londres, vol. 29, n. 4, 2013, p. 708-710.

212 OOSTERLINCK, K. Sovereign Debt Defaults: Insights from History. Oxford Review of Economic Policy, Londres, vol. 29, n. 4, 2013, p. 709.

213 COLLET, S. A Unified Italy? Sovereign Debt and Investor Skepticism. Bruxelas, 2012. Mimeo.

${ }^{214} \mathrm{Na}$ versão em inglês da convenção, o artigo 37.2 tem a seguinte redação: "[i]n the absence of such na agreement, the State debt of the predecessor State shall pass to the successor State in an equitable proportion, taking into account, in particular, the property, rights, and interests which pass to the successor State in relation to that State debt" (Vienna Convention on Succession of States in respect of State Property, Archives and Debt, 8/4/1983, sem vigor). 
parâmetros para as negociações dos tratados internacionais relacionados, não é capaz de pôr fim, sozinho, às incertezas dos credores do Estado. Seja porque se desconhecem os critérios de repartição dos encargos para Estados novos, seja porque há o risco de reestruturação ou inadimplemento absoluto caso não haja sucessão total na dívida pública.

\subsubsection{Inadimplemento absoluto: o repúdio da dívida odiosa}

Há situações em que a inexecução da dívida pública vai além de modificações contratuais e atinge a totalidade da obrigação, com seu cancelamento pelo Estado devedor (quando se pode falar de inadimplemento absoluto) em razão de alegados vícios na constituição ou na evolução dos pagamentos. Dadas as especificidades técnicas do tema, esta hipótese costuma vir referida como o repúdio da dívida pública, o qual mantem relações dinâmicas com os processos de reestruturação expostos acima. As modificaçóes objetivas pelas quais se diminuem os reembolsos ou se prolongam as maturidades podem vir acompanhadas de afirmações públicas de questionamento da legitimidade da dívida assumida, ou de ameaças de suspensão de pagamentos com esse fundamento. Com o objetivo de obter condições de reestruturação mais favoráveis, a importância do inadimplemento, como fato ou como potencialidade, não deve ser afastada dos processos de renegociação da dívida pública. Neste sentido, é conveniente analisar as chaves de interpretação jurídica do fenômeno do repúdio da dívida pública e do cancelamento do dever de realizar os pagamentos.

Se for possível identificar entre as diversas correntes interpretativas uma única ideia-força subjacente ao repúdio da dívida pública, ela estará na distinção entre a dívida pública do Estado e a de um regime político temporário, o que permite discernir a eventual ilegitimidade dos compromissos anteriormente assumidos. Esta modalidade de descumprimento da obrigação financeira se associa, portanto, a uma atitude deliberada de cancelamento de uma determinada classe da dívida pública, não à carência de meios disponíveis ao serviço da dívida. O repúdio é forma de atuação da soberania que caracteriza inexecução direta das obrigações financeiras, pois afeta os empréstimos públicos em suas características jurídicas; não caberia, aqui, falar de modalidades indiretas pelas quais os contratos seriam atingidos a partir dos efeitos econômicos que sobre eles recairiam a partir de uma dada decisão estatal, tal como a reforma monetária. ${ }^{215}$ É possível, entretanto, cogitar de formas sinuosas de repúdio que não envolvam uma declaração formal. Assim,

215 FONROUGE, G. Derecho Financiero. 3. ed. Buenos Aires: Depalma, 1977, vol. 2, p. 1048. 
podem-se identificar situações descritíveis como repúdio que se expressam de maneira óbvia ou dissimulada, conforme, no primeiro caso, o Estado expressamente se recuse a adimplir uma ou dada classe de obrigaçóes, ou recorra, no segundo, a conversóes forçadas que caracterizariam forma de expropriação total ou parcial de capitais. ${ }^{216}$ Qualquer que seja a manifestação, uma declaração de repúdio repousa, ou ao menos assim se justifica retoricamente, sobre fundamentos que atinam à constituição, à forma de cumprimento e à finalidade da obrigação. Não há, por assim dizer, uma única doutrina do repúdio da dívida; ele é justificado por fundamentos variáveis, que podem ser relacionados à irregularidade dos procedimentos de autorização da dívida pública, à alegação de juros excessivos que se tachariam de usura, ou ainda à destinação dos recursos para objetivos contrários ao interesse público. Estes são argumentos que permitiriam distinguir os encargos que comprometem o Estado daqueles que se associam apenas a um governo temporário o qual, ao agir de forma ilegítima ou a comprometer com injustificável excesso as receitas públicas, não vinculariam prolongadamente o ente soberano.

Este debate se liga fortemente à instável doutrina jurídica da dívida odiosa. Embora seja um tema que remonta a uma importante tradição do debate sobre a dívida pública, sua atualidade é evidente. Com a deposição de Saddam Hussein do governo iraquiano em 2003, o governo dos Estados Unidos deparou-se com a necessidade de oferecer alguma resposta à questão das dívidas vincendas do regime. A dívida pública iraquiana, que se constituía, na maior parte, como dívida oficial, sendo de pouco significado a parcela relativa a credores privados, foi então reestruturada junto ao Clube de Paris, ainda que sem dizer expressamente que se o fazia pelo caráter "odioso". ${ }^{217}$ Alegou-se, então, a necessidade de recuperar a economia iraquiana, algo que não explica satisfatoriamente, porém, as significativas reduções obtidas no Clube. Esta discussão ganhou, então, a dimensão de um assunto de interesse global, retomando a antiga doutrina da não aderência ao Estado da dívida de regimes despóticos. Países como Noruega e Equador se esforçaram desde então para manter vivo o debate, pedindo pela inclusão do tema da dívida ilegítima na

216 INGROSSO, G. Corso di Finanza Pubblica. Napoli: Casa Editrice Dott. Eugenio Jovene, 1969, p. 586.

217 'Proponents of a doctrine of 'odious' debt assert that some of Iraq's debt's could potentially be classified as non-legitimate under international law since they were undertaken during the Hussein regime and that international law should be able to expunge these debts. The concepto f 'odious' debt does not appear to be well established in international law" (WEISS, M. Iraq's Debt Relief: Procedure and Potential Implications for International Debt Relief. CRS Report for Congress RL 33376, Washington, D.C., 21/4/2006, p. 15). 
agenda de desenvolvimento das Naçôes Unidas. ${ }^{218}$ Parte desse interesse nasce de problemas materializados em questôes políticas concretas, entre as quais se situa o interesse equatoriano no assunto após a instalação de uma comissão de auditoria de sua dívida pública, em 2008. Esta comissão apontou irregularidades substanciais em alguns dos empréstimos tomados a partir do ano de 2000, razão pela qual se suspenderam os pagamentos de algumas modalidades de títulos públicos. Assim, o default não se deu em razão de qualquer forma de incapacidade de pagamento, mas do alegado caráter ilegítimo da dívida emitida. Uma grande maioria dos credores aceitou, então, a oferta de reestruturação feita pelo governo, com a redução nos reembolsos de cerca de dois terços do valor nominal. ${ }^{219}$

Longe, como visto, de ser uma questão meramente especulativa, tenta-se erigir a legitimidade da dívida como um princípio jurídico a disciplinar os pagamentos da dívida externa, e alguns Estados têm mostrado disposição para posicionar o tema na agenda internacional. Ao menos do ponto de vista teórico, o desenvolvimento da noção de dívida odiosa é recente, posto que os defaults de Estados sejam fenômenos antiquíssimos. A noção que se poderia chamar clássica do repúdio é aquela que se manifesta a partir de sua primeira formulação em 1927 como uma doutrina da inexecução da dívida pública por motivos justificados, o que se fez pelo trabalho do russo Alexander Sack, referência fundamental sobre o tema. Aí se procuraram firmar critérios de reconhecimento do caráter odioso da dívida a partir dos efeitos que acarretavam transformações políticas sobre as obrigações financeiras pré-existentes. ${ }^{220}$ Com a anulação pelo governo bolchevique, em 1918, dos antigos empréstimos do império russo, colocaram-se diversas questôes que exigiam tratamento do ponto de vista jurídico.

Sack estabeleceu, então, três critérios que, se atendidos, legitimariam o repúdio da dívida em situações de alteração do regime político. Assim, se o regime que contraiu a dívida era despótico (isto é, não contava com o consentimento do povo), se os capitais não foram empregados em benefício do povo, e se os credores sabiam do provável desvio de finalidade dos recursos que emprestavam ao Estado, então se poderia falar de dívida odiosa. ${ }^{221}$ Consoante esta clássica elaboração, o regime

${ }^{218}$ LUDINGTON, S.; GULATI, M.; BROPHY, A. Applied Legal History: Demystifying the Doctrine of Odious Debts. Theoretical Inquiries in Law, Israel, vol. 11, 2010, p. 248.

219 Para o caso equatoriano, ver EQUADOR. Comisión de Auditoria Integral del Crédito Público. Informe de la Subcomisión Jurídica, Quito, 23/9/2008.

${ }^{220}$ Les Effets des Transformations des États sur Leurs Dettes Publiques et Autres Obligations Financières. Paris: Recueil Sirey, 1927.

221 SACK, A. Les Effets des Transformations des États sur Leurs Dettes Publiques et Autres Obligations Financières. Paris: Recueil Sirey, 1927, p. 157-163. 
sucessor não estaria obrigado às dívidas contraídas (i) sem consentimento do povo, (ii) sem benefício para o povo e (iii) com conhecimento pelos emprestadores destes vícios. A razão do afastamento da responsabilidade pela obrigação financeira estaria no caráter pessoal da dívida assumida por governantes corruptos, que se tornariam os únicos responsáveis por ela. Os critérios são afeitos aos procedimentos de autorização da dívida pública, mas não apenas. Ainda que se possam observar variações nos respectivos direitos internos sobre a distribuição do poder financeiro entre governo e parlamento, a tomada de empréstimos não legitimada por procedimentos democráticos de autorização parlamentar e afastada de sistemas de controle jurídico e político escusariam o Estado de seu posterior cumprimento. ${ }^{222}$ Não basta, no entanto, que a dívida tenha sido contraída por um governo tirânico; seu aproveitamento, ainda que não imediato, ao povo que a ela se obriga e a convicção, da parte dos credores, de que o emprego dos recursos se daria em benefício do país excluiriam o caráter odioso da dívida. Pela doutrina clássica, os três critérios deveriam ser simultaneamente obedecidos para que não houvesse a transmissão das obrigações ao regime sucessor, "como três cerejas em um caça-níquel". ${ }^{223}$ Emergem desta necessária concomitância duas finalidades: livrar o povo dos encargos financeiros de uma dívida não consentida e desestimular credores privados a conceder empréstimos a regimes políticos ilegítimos.

Pelo ponto de vista de uma exclusiva postulação moral, seria possível, para argumentar apenas, admitir que a dívida obtida nas odiosas condiçóes expostas por Sack não devesse ser paga. Esta é a perspectiva esposada por muitos comentadores que apontam os problemas da gênese da dívida de países em desenvolvimento, como se nota na crítica religiosa à dívida do terceiro mundo. ${ }^{224}$ Em extenso exame dos fundamentos éticos do default em tais circunstâncias, Buchanan introduz ainda o interessante dilema que surge quando se devem oferecer prêmios de risco cada vez maiores para que, em um mercado nos quais os preços são determinados de forma competitiva, a antecipação do risco de default pelos agentes econômicos os induza a exigir rendimentos crescentes para que continuem a emprestar recursos ao

222 Sobre o sentido democrático dos procedimentos parlamentares de autorização da dívida pública e sua relação com os princípios orçamentários, cf. HÖFLING, W. Staatsschuldenrecht: Rechtsgrundlagen und Rechtsmaßstäbe für die Staatsschuldenpolitik in der Bundesrepublik Deutschland. Heidelberg: C. F. Müller, 1993, p. 17 e seguintes.

223 BUCHHEIT, L.; GULATI, G.; THOMPSON, R. The Dilemma of Odious Debts. Duke Law Journal, Durham, vol. 56, s. n., 2007, p. 1218.

${ }^{224}$ JOBLIN, J. Les Rouages de l'Economie Mondiale au Regard de l'Ethique. Application au Probleme de la Dette. Le point de Vue de l'Eglise. In: VIADEL, A. C.; MONTORO, A. F. La Deuda Externa: Dimensión Política y Jurídica. Madri: Iepala Editorial, 1999. 
Estado. Algo que poderia levar os contribuintes-beneficiários do instante de contração dos empréstimos a se obrigarem ao seu pagamento pela moralidade do princípio pacta sunt servanda, mas que não enfrenta satisfatoriamente o problema da vinculação das gerações futuras ao pagamento de uma dívida pública encarecida pela interrupção dos pagamentos feitos pelos seus antecessores. Seria justo, assim, que gerações mais recentes arcassem com os custos provocados por geraçôes anteriores? Com o transcurso do tempo, a redução dos pagamentos da dívida pública deve ser necessariamente renegociada, segundo o citado economista, dado o irrealismo de percepções do risco ultrapassadas, cuja precificação nos contratos não encontre mais respaldo na atual possibilidade de default. ${ }^{225}$ Haveria, assim, algum sentido moral na ideia do repúdio, exposto tanto na onerosidade excessiva para os países mais pobres, como também nos encargos para gerações futuras que talvez não tenham as mesmas inclinações para a moratória que seus antecessores.

Os problemas começam a surgir, contudo, quando se pretende erigir a doutrina da dívida odiosa a uma norma de direito internacional. Estas dificuldades se originam de certa vagueza e indeterminação que só têm se ampliado nas manifestações mais recentes em favor do repúdio. Nas ocasiôes em que se lançou mão de termos fortes da doutrina, tais como "regime despótico" e "dívida odiosa", para cancelar, ou ao menos reduzir, as obrigações incorridas por governos ditatoriais, o pleito ganhou formulação ainda mais ampla. Assim mostram os exemplos das sucessões dos regimes ditatoriais de Marcos nas Filipinas, de Somoza na Nicarágua e dos Duvaliers no Haiti. ${ }^{226}$ Em sentido semelhante, a Comissão da Verdade e Reconciliação da África do Sul pediu pela declaração da ilegitimidade e pelo cancelamento da dívida contraída pelo regime do apartheid para financiar a repressão à maioria negra daquele país. ${ }^{227} \mathrm{Com}$ isto, pretendeu-se extrair o caráter odioso dos empréstimos a partir da própria ilegitimidade dos regimes jurídicos que os contraíram. A pretendida nulidade se estenderia a toda a dívida pública, e não apenas a operações de crédito específicas. Neste sentido se fala de uma transformação da doutrina da dívida odiosa em uma doutrina da dívida ilegítima, a partir da qual se presumiria a ilegitimidade da dívida de ditaduras. ${ }^{228}$ Uma significativa ampliação

${ }^{225}$ BUCHANAN, J. The Ethics of Debt Default. In: BUCHANAN, J.; ROWLEY, C.; TOLLISON, R. (Coord.). Deficits. Delhi: Disha Publications, 1989, p. 361-374.

${ }^{226}$ KREMER, M.; JAYACHANDRAN, S. Odious Debt. Finance and Development, Washington, D.C., vol. 39, n. 2, jun. 2002, p. 7 e seguintes.

227 Cf. HOWSE, R. The Concept of Odious Debt in Public International Law. UNCTAD Discussion Papers, Genebra, n. 185, jun. 2007, p. 8.

228 BUCHHEIT, L.; GULATI, G.; THOMPSON, R. The Dilemma of Odious Debts. Duke Law Journal, Durham, vol. 56, s. n., 2007, p. 1212. 
das ideias originais de Sack, que previra a necessidade de procedimentos específicos, preferencialmente perante um tribunal internacional, para o reconhecimento da possibilidade jurídica do repúdio, em que o ônus da prova caberia ao Estado devedor. ${ }^{229}$ No campo doutrinário, uma definição assim tão abrangente é dada, por exemplo, por J. Hanlon, que associa a dívida odiosa a toda operação em que os desvios de comportamento do tomador do empréstimo o tornem ilegítimo. ${ }^{230}$

Essa imprecisão torna o conceito de dívida odiosa de aplicação difícil, e já se chegou a cogitar do risco de seu emprego arbitrário. ${ }^{231}$ Trata-se de uma questão extremamente delicada a existência de alguma norma internacional a esse respeito. Para respondê-la, é preciso recorrer às fontes do direito internacional, que, segundo o artigo 38 do Estatuto da Corte Internacional de Justiça, são as convenções internacionais, o costume, os princípios gerais de direito e a doutrina. Uma observação analítica destas fontes pode indicar em que condiçōes se poderia pleitear o caráter normativo da ilegitimidade da dívida pública compreendida em dadas circunstâncias.

Com relação às convenções internacionais, as discussões da Comissão de Direito Internacional (International Law Commission) sobre a preparação da Convenção de Viena sobre a Sucessão de Estados em matéria de Bens, Arquivos e Dívidas do Estado evidenciam as dificuldades do reconhecimento de um direito ao repúdio da dívida de regimes corruptos, autoritários e perdulários. Por sugestão do Relator Especial Bedjaoui, incluiu-se no projeto da convenção uma definição dúplice da dívida odiosa, a qual compreenderia "todas as dívidas contraídas pelo Estado predecessor com vistas a atingir objetivos contrários aos maiores interesses do Estado sucessor ou do território transferido", mas também "todas as dívidas contraídas pelo Estado predecessor com um objetivo e um propósito em desconformidade com o direito internacional e, em particular, com os princípios de direito internacional incorporados à Carta das Naçôes Unidas”. ${ }^{232}$ A primeira definição, mais

229 SACK, A. Les Effets des Transformations des États sur Leurs Dettes Publiques et Autres Obligations Financières. Paris: Recueil Sirey, 1927, p. 42.

${ }^{230}$ Defining "Illegitimate Debt": When Creditors Should be Liable for Improper Loans. In: JOCHNICK, C.; PRESTON, F. (Coord.). Sovereign Debt at the Crossroads: Challenges and Proposals for Resolving the Third World Debt Crisis. Oxford: Oxford University Press, 2006, p. 118.

231 "The doctrine of odious debt is a dangerous one which (...) 'favours most arbitrary and iniquitous solutions'” (O'CONNELL, D. P. The Law of State Succession. Cambridge: Cambridge University Press, 1956, p. 190).

232 BEDJAOUI, M.Succession of States in Respect of Matters other than Treaties. In: NAÇÕES UNIDAS. Yearbook of the International Law Commission. Nova Iorque: Naçôes Unidas, 1977, vol. II, parte I, p. 134. 
próxima da tradicional, confere maior ênfase aos interesses do Estado sucessor prejudicados pela transmissão dos débitos; a segunda, por sua vez, invoca os prejuízos à comunidade internacional, cujos princípios gerais se veriam violados pela natureza odiosa da dívida. Esta mudança de enfoque é importante. A conceituação clássica da dívida odiosa, expressa na primeira definição, poderia indicar alguma forma de ingerência de instituiçõos internacionais em decisões políticas e econômicas internas, pois caberia a alguma instância externa decidir se houve algum prejuízo ilegítimo à população do Estado sucessor pela transmissão das obrigações financeiras - algo que entra em potencial conflito com o poder de decisão de instituições democráticas internas. Ao transferir o parâmetro de análise para os princípios de direito internacional, entretanto, Bedjaoui desloca o caráter ilegítimo da dívida dos órgãos internos ao campo de análise próprio de instituições internacionais. ${ }^{233}$ Qualquer menção à dívida odiosa foi, porém, rejeitada na redação final da convenção. C. Paulus afirma que esta rejeição se deu "sem deixar traço" no novo texto. ${ }^{234}$ Algum traço, porém, existe na parte final do artigo 33, que conceitua a dívida pública como qualquer obrigação financeira em conformidade com o direito internacional. ${ }^{235}$ Houvesse entrado em vigor, a Convenção de 1983 ofereceria, nesta restrição, caminhos de reconhecimento para a legitimidade da dívida pública como um elemento de sua exigibilidade. Tem razão Paulus, no entanto, de que não há marcas de qualquer referência explícita à dívida odiosa em convenções internacionais.

À segunda fonte mencionada no Estatuto da CIJ, o costume. Para que a dívida odiosa fosse reconhecida como parte do direito internacional costumeiro, seria preciso que passasse pelo difícil teste de uma prática consistente dos Estados ao longo do tempo para que se firmasse sua ampla aceitação normativa, que ultrapassasse qualquer aplicação ocasional. Ao lado deste dado objetivo, o elemento subjetivo da opinio juris deveria ficar claro em declaraçóes do Estado, em quaisquer formas que se apresentassem, tais como documentos e declarações oficiais. Portanto, como foi afirmado no caso da Plataforma Continental do Mar do Norte, não basta que os atos em questão constituam uma práxis estabelecida, mas é necessário que também carreguem alguma evidência da convicção de sua juridicidade. ${ }^{236}$

233 Cf. MICHALOWSKI, S. Unconstitutional Regimes and the Validity of the Sovereign Debt: a Legal Perspective. Chippenham: Ashgate, 2007, p. 69.

234 The Evolution of the Concept of Odious Debt. Zeitschrift für ausländisches öffentliches Recht und Völkerrecht, Munique, vol. 68, 2008, p. 415-416.

235 Ver nota 205.

236 North Sea Continental Shelf Cases, CIJ, 1969, p. 44, em que se lê: “[n] ot only must the acts concerned amount to a settled practice, but they must also be such, or be carried out in such a 
A dívida odiosa foi expressamente invocada em um escasso número de controvérsias, algo que compromete tanto a prática como a formação da opinio juris. ${ }^{237}$ De um lado, os eventos de sucessão de Estados fornecem número maior de situações em que as dívidas de guerra obtidas para combater movimentos de independência ou de insurgência civil ao depois vitoriosos foram reconhecidas como o núcleo duro das dívidas odiosas; ${ }^{238}$ o problema, porém, é que, tanto na definição de Sack como nas conceituações mais recentes, o caráter "odioso" se aproxima também de motivos mais abrangentes de ilegitimidade da dívida, o que faz com que a ideia seja de difícil concreção jurídica. Para Gelpern, os inúmeros regimes ditatoriais do século XX colocaram as doutrinas da ilegitimidade da dívida pública em algum relicário do direito internacional, dada a insegurança que traria sua aplicação às diversas revoluções políticas do período. Mesmo após uma aparente tentativa de reinvocá-las após a deposição do regime de Saddam Hussein nos primeiros anos do século, a reestruturação da dívida iraquiana deu-se concretamente sob o argumento de que seria preciso restaurar a economia do país - e não, portanto, sob o influxo da ilegitimidade de sua contração e destinação. ${ }^{239}$ A ideia de que se renegociava a dívida por seu caráter odioso foi, aliás, expressamente rejeitada pelos negociadores iraquianos. ${ }^{240}$ Não se trata, aqui, de negar a existência de numerosos casos em que a dívida pública foi repudiada, que vão além dos exemplos já mencionados.

way, as to be evidence of a belief that this practice is rendered obligatory by the existence of a rule of law requiring it. The need for such a belief, i. e., the existence of a subjective requirement, is implicit in the very notion of the opinio juris sive necessitatis. The States concerned must therefore feel that they are conforming to what amounts to a legal obligation. The frequency, or even habitual character of the acts is not in itself enough. There are many international acts e.g., in the field of ceremonial and protocol, which are performed almost invariably, but which are motivated only by considerations of courtesy, convenience or tradition, and not by any sense of legal duty."

237 GELPERN, A. Odious, not Debt. Law and Contemporary Problems, Durham, vol. 73, n. 4, 2010, p. 85-86.

238 Ver REINISCH, A.; HAFNER, G. Staatensukzession und Schuldenübernahme beim "Zerfall” der Sowjetunion. In: DORALT, P.; HASCHEK, H.; SCHAUER, M. (Coord.). Schriftenreihe des Forschungsinstituts für Mittel- und Osteuropäisches Wirtschaftsrecht. Viena: Service Fachverlag, 1995, vol. 9, p. 71.

239 GELPERN, A. What Iraq and Argentina Might Learn from Each Other. Chicago Journal of International Law, vol. 6, n. 1, 2005, p. 406.

240 "Iraq's need for very substantial debt relief derives from the economic realities facing a post-conflict country that hás endured decades of financial corruption and mismanagement under the Saddam regime. Principles of public international law such as the odious debt doctrine, whatever their legal vitality, are not the reason why Iraq is seeking this relief" (MAHDI, A. A. apud GELPERN, A. What Iraq and Argentina Might Learn from Each Other. Chicago Journal of International Law, vol. 6, n. 1, 2005, p. 406). 
Para além do repúdio da dívida tsarista depois da Revolução Russa, podem-se citar o cancelamento da dívida mexicana junto a vários estados europeus em 1867, o cancelamento da dívida com a Prússia tomada para a colonização da Polônia em 1919, a dívida pré-revolucionária da China caracterizada como odiosa nos litígios instalados em 1952, as obrigações financeiras perante a administração francesa na Argélia em 1962, as reclamações do Irã quanto a débitos pré-revolucionários destinados ao armamento de grupos que apoiavam o xá, decidida desfavoravelmente ao regime islâmico em 1996. ${ }^{241}$ Trata-se de reconhecer, no entanto, que todas as questôes foram disputadas e a alegação do caráter odioso da dívida obteve resultados bastante díspares. É conveniente verificar na jurisprudência de cortes e tribunais os casos mais relevantes a respeito, a seguir selecionados.

De fato, não será mais promissora a busca do reconhecimento da doutrina da dívida odiosa nas decisões de tribunais arbitrais, que oferecem exemplos de sua invocação por alguma das partes. Esses casos, que já datam de algum tempo, exibem a baixa frequência de sua menção. Há um único caso em que se reconheceu a invalidade da dívida pública com fundamento em sua ilegitimidade. Se, de um lado, a análise da jurisprudência dos tribunais arbitrais indica as poucas perspectivas que existem para o sucesso do argumento, o caso Tinoco (1923), entre Grã-Bretanha e Costa Rica, se destaca como uma exceção.

Aí se examinou a validade da emissão de títulos públicos sob o governo ditatorial de Frederico Tinoco. Após sua fuga do país, em 1919, o novo governo editou lei que invalidava as transaçôes financeiras do regime anterior. O governo britânico afirmava que a Costa Rica deveria, no entanto, satisfazer as obrigaçôes em posse do Royal Bank of Canada. O governo costa-riquenho, por sua vez, alegava que o governo de Tinoco não era legítimo nem de jure nem de facto, de forma que o país não se vincularia aos compromissos assumidos por ele. ${ }^{242}$ Segundo a decisão do árbitro Taft, então presidente da Suprema Corte dos Estados Unidos, a lei interna da Costa Rica não teria efeitos no direito internacional, pois a mudança de regime não afetaria as obrigações internacionais do Estado. Com isto se reconheceu que Tinoco exercia um governo de fato sem resistência substancial. Além disso, a violação do direito constitucional interno havia sido parte do processo revolucionário de tomada do poder, e o direito internacional não teria como base do reconhecimento jurídico de um governo exclusivamente a sua legitimidade constitucional.

241 KING, J. Odious Debt: the Terms of the Debate. North Carolina Journal of International Law, Chapel Hill, vol. 32, n. 4, 2007, p. 634-636.

242 NAÇÕES UNIDAS. Tinoco Arbitration (Grã-Bretanha v Costa Rica). Reports of International Arbitral Awards, vol. 1, 18/10/1923, p. 369-399. 
A sentença arbitral foi concluída, no entanto, de forma surpreendente, e considerou que a concessão de crédito, pelo banco canadense, ao governo de Tinoco em sua fase final foi ilegitimamente empregada sem que a instituição financeira se preocupasse em garantir que seu uso se desse em proveito do governo da Costa Rica, e não em proveito pessoal do ditador. Ao contrário, o árbitro entendeu demonstrado que o banco tinha conhecimento de que os capitais não seriam empregados em finalidades governamentais. De fato, era de conhecimento do banco que os recursos seriam usados para a preparação da fuga de Tinoco e para garantir posteriormente suas condições de vida no país de refúgio. Não seria exigível, segundo o árbitro Taft, que a dívida assumida para prover de recursos a pessoa do ditador e seus familiares devesse ser paga pelo governo restaurado da Costa Rica. O mesmo foi dito dos recursos destinados à legação do país na Itália, chefiada pelo irmão do ditador. A finalidade formal do empréstimo, que havia sido registrada como um incomum adiantamento salarial de quatro anos, foi entendida como mero pretexto para o desvio dos recursos que seriam usados para sustentar o refugiado no exterior. ${ }^{243}$ As perdas, em vez de pesar sobre o novo governo, deveriam recair sobre a casa bancária que, de acordo com a compreensão do árbitro, tinha pleno conhecimento da finalidade dos recursos emprestados.

$\mathrm{Na}$ quase totalidade dos casos, no entanto, a doutrina da dívida odiosa foi rejeitada. O primeiro deles tratou-se do Caso das Reclamações Francesas contra o Peru, que teve por base a venda de guano, em 1869, à casa bancária Dreyfus Frères \& Cie, instituição francesa que posteriormente receberia a proteção diplomática de seu governo. ${ }^{244} \mathrm{Em}$ troca do insumo, o banco francês adiantava ao Peru recursos usados para o serviço de dívidas vincendas. Neste ínterim sobreveio, em 1879, a guerra chileno-peruana que levaria o ditador Piérola ao poder, o qual aceitara pagar apenas parte do que devia a Dreyfus; após sua deposição, no entanto, o congresso peruano, neste como em outros casos, aprovou uma lei que declarava nulos todos os atos e contratos praticados pelo ditador. $\mathrm{O}$ novo governo se recusava, portanto, a reembolsar Dreyfus em qualquer quantia. $\mathrm{O}$ caso foi submetido a um primeiro tribunal arbitral. Abstraídos alguns detalhes do caso, a questão central foi a prioridade de pagamentos que um decreto chileno havia conferido a determinadas classes de credores: assim, o governo peruano transferia para um fundo no Banco da Inglaterra os recursos que seriam distribuídos aos credores. O banco Dreyfus e

243 NAÇÕES UNIDAS. Tinoco Arbitration (Grã-Bretanha v Costa Rica). Reports of International Arbitral Awards, vol. 1, 18/10/1923, p. 394.

${ }^{244}$ NAÇÕES UNIDAS. French Claims against Peru Case (França v Peru). Reports of International Arbitral Awards, vol. 1, 11/10/1921. 
outros portadores de títulos de nacionalidade francesa argumentavam que, a ser satisfeita a dívida por esta via, se desrespeitariam as garantias contratuais diferenciadas dos contratos a eles relativos, consistentes no oferecimento dos depósitos de guano como segurança dos empréstimos, ao passo que o Peru dizia que estes recursos poderiam ser usados para pagar todos os credores. Pela opinião do tribunal, não haviam sido previstos direitos preferenciais no fundo, pelo que os seus recursos poderiam ser distribuídos pro rata, decisão que não satisfez aos credores franceses e que custou ao país sul-americano o direito de operar naquele importante mercado financeiro. Em consequência, o Peru abdicou de sua posição de non possumus relativa a parte de sua dívida com aquele país e aceitou pagar 25 milhões de francos exclusivamente aos franceses, algo que, para aumentar a complexidade do caso, foi rejeitado pelo congresso peruano em razão do não reconhecimento das dívidas do período ditatorial. ${ }^{245} \mathrm{~A}$ disputa foi então submetida ao Tribunal Permanente de $\mathrm{Ar}$ bitragem, em Haia, que decidiu pela exigibilidade dos créditos franceses contra o Peru devido ao reconhecimento internacional de que gozava o governo de Piérola, cujos atos, em representação do governo peruano, seriam vinculantes ao Estado. A lei interna que invalidara os empréstimos não atingiria os estrangeiros, que, de boa-fé, colocaram capitais à disposição do Peru. ${ }^{246}$

Apesar do não reconhecimento da invalidade da dívida peruana, adotou-se, no caso das Reclamações Francesas, uma solução negociada para o pagamento da dívida por meio da qual o Peru voltou a obter acesso aos mercados financeiros. Em outros casos importantes o mesmo não ocorreu. Os empréstimos da Administração Postal Portuguesa ao governo da Croácia durante o período em que aquele país esteve sob ocupação alemã, nos anos da Segunda Guerra, foram questionados pelo governo sucessor porque não se reconhecia a dívida assumida por um governo dito marionete. ${ }^{247}$ Em 1956 se instalou, então, um tribunal arbitral nos termos da Convenção Postal Universal, o qual, conquanto afirmasse sua jurisdição para conhecer da matéria e a existência de fatos que justificassem a reclamação, não reconheceu sua jurisdição sobre a questão central, que consistia na responsabilidade da Iugoslávia pelos débitos assumidos durante períodos de ocupação. Ainda que não tenha

${ }^{245}$ WYNNE, W. State Insolvency and Foreign Bondholders: Selected Case Histories of Governmental Foreign Bond Defaults and Debt Readjustments. Washington, DC: Beard Books, vol. II, p. 164 e seguintes.

${ }^{246}$ NAÇŌES UNIDAS. French Claims against Peru Case (França v Peru). Reports of International Arbitral Awards, vol. 1, 11/10/1921, p. 218-20.

247 Ver UNIĀO POSTAL UNIVERSAL. Dues for Reply Coupons Issued in Croatia; Re Transit Charge for Mails from Occupied Yugoslavia (Administração Postal de Portugal v Administração Postal da Iugoslávia), 1956, p. 90A. 
enfrentado o mérito da questão, o tribunal arbitrou considerou, entretanto, que seria necessário um acordo internacional (ou alguma outra manifestação inconteste) para que se reconhecesse a sucessão da Iugoslávia nas dívidas croatas tomadas no período aqui exposto. Não havendo disposição convencional, deixou-se também de reconhecer o direito da administração postal portuguesa aos reembolsos. Veja-se, então, que a base da decisão foi a ausência de tratado que regulasse a sucessão nas dívidas públicas croatas, e não a sua ilegitimidade. ${ }^{248}$

Finalmente, os princípios gerais de direito são interpretados, em relação à dívida odiosa, por duas correntes principais. A primeira delas se utiliza de princípios jurídicos amplamente reconhecidos por diversas ordens jurídicas para justificar, no direito internacional, a inexecução de determinadas obrigações financeiras tidas como repudiáveis. Assim, os princípios jurídicos da boa-fé e da proibição do abuso de direito para equiparar a pretensão de recuperar os valores emprestados a governos ilegítimos ou sabidamente corruptos a um abuso dos direitos contratualmente assegurados. ${ }^{249} \mathrm{O}$ abuso de direito, fórmula de longa tradição jurídica, se associa aos danos causados a outrem pelo exercício de um direito, com o consequente dever de reparação do dano caso tenha havido a intenção de produzi-lo. O reconhecimento da proibição do abuso de direito no âmbito internacional, porém, se ampara em uma doutrina modesta, ${ }^{250}$ e tem seus parâmetros apenas escassamente delineados em decisões de tribunais internacionais. É o que pode ser observado no Caso Relativo a Certos Interesses Alemães na Alta Silésia Polonesa, ${ }^{251}$ no qual se restringiu a possibilidade de disposição de propriedades alemãs em território polonês caso a alienação tivesse por resultado algum abuso no exercício daqueles direitos, e no Caso das Zonas Francas, em que a Corte estabeleceu a aplicabilidade da legislação tributária francesa a áreas de favorecimento fiscal desde que esta aplicação não constituísse nenhuma forma de abuso - o qual, no entanto, não se presumiria. ${ }^{252}$ Ainda no âmbito de princípios jurídicos tradicionais, alguns trabalhos procuram sustentar a doutrina da dívida odiosa na proibição do enriquecimento

248 WAIBEL, M. Sovereign Defaults before International Courts and Tribunals. Cambridge: Cambridge University Press, 2011, p. 141-141.

249 Cf. FRANKENBERG, G.; KNIEPER, R. Legal Problems of Overindebtedness of Developing Countries: the Current Relevance of the Doctrine of Odious Debts. Safat: The Industrial Bank of Kuwait, 1984, p. 428.

250 Como comenta BROWNLIE, I. Principles of Public International Law. 7. ed. Nova Iorque: Oxford University Press, 2010, p. 562.

251 Case Concerning Certain German Interests in Polish Upper Silesia, CPJI, série A, n. 7, 1926.

${ }^{252}$ Case of the Free Zones of Upper Savoy and the District of Gex, CPJI, série A, n. 22, 1929. 
sem causa, particularmente mencionado nos casos de sucessão de Estados. ${ }^{253}$ Esta postulação é mais problemática pois, para que se afirmasse a falta de fundamentos jurídicos para o benefício dos credores, seria necessário que os contratos de que são parte fossem inválidos, o que exigiria, então, definir os critérios pelos quais poderiam ser assim qualificados. A dívida pública seria, então, odiosa porque o enriquecimento dos credores é ilícito, mas seu enriquecimento seria qualificado de ilícito porque a dívida é odiosa, o que produz uma estranha tautologia. Este princípio é, portanto, pouco funcional para sustentar o caráter odioso como principal argumento do repúdio à dívida, o qual deveria partir, inevitavelmente, de uma análise dos contratos e de sua invalidação. ${ }^{254}$

A segunda das abordagens diz respeito à extensão dos princípios reconhecidos na casuística de tribunais nacionais ao âmbito internacional. Por ser a lei aplicável mais frequente, a lei de Nova Iorque fornece o melhor exemplo desta perspectiva, ao fundamentar o eventual reconhecimento da possibilidade jurídica do repúdio no caráter fiduciário das obrigações dos representantes de agir no interesse dos representados (law of agency). Ao emitir dívida pública que contrarie os procedimentos constitucionais de autorização ou que seja empregada sem benefício para o Estado e a população que lhe delegou os poderes de ação, a autoridade pública agiria para além dos seus poderes. Esta ação justificaria o repúdio das obrigações contraídas ultra vires. $\mathrm{O}$ argumento tem, no entanto, mais relevância jurídica em tribunais nacionais do que em experiências relativas ao direito internacional, e mesmo a aplicação pelos órgãos internos do Estado encontra critérios restritos e precedentes vacilantes. ${ }^{255} \mathrm{~A}$ transposição para o direito internacional não é, assim, imediata. As relações jurídico-políticas que se estabelecem entre os agentes, de um lado, e o Estado e a população, de outro, não se identificam imediatamente com as obrigações fiduciárias contratualmente definidas. Ao lado da natureza constitucional desta representação, a transposição, para o direito internacional, da jurisprudência de Nova Iorque como um princípio geral de direito exporia outros conflitos quanto aos diferentes fundamentos e regras de atuação de cada um dos espaços normativos em questão.

253 Como faz O'CONNELL, D. P. State Succession in Municipal Law and International Law. 2. ed. Cambridge: Cambridge University Press, 1967, p. 14-15.

${ }^{254}$ KING, J. Odious Debt: the Terms of the Debate. North Carolina Journal of International Law, Chapel Hill, vol. 32, n. 4, 2007, p. 643; MICHALOWSKI, S. Unconstitutional Regimes and the Validity of the Sovereign Debt: a Legal Perspective. Chippenham: Ashgate, 2007, p. 44.

255 Para a defesa da aplicabilidade da law of agency por tribunais de estados norte-americanos para casos de repúdio da dívida, ver BUCHHEIT, L.; GULATI, G.; THOMPSON, R. The Dilemma of Odious Debts. Duke Law Journal, Durham, vol. 56, s. n., 2007, p. 1237-1245. 
A ausência de uma doutrina jurídica uniforme e as ambiguidades das fontes do direito internacional expõem o flanco aberto das estruturas jurídicas das dívidas ilegítimas. De um lado, sua conceituação é imprecisa e tendente a uma ampliação que a torna mais vaga. De outro, a matéria não é disciplinada por convenções internacionais e a prática dos Estados tem resultados desiguais sobre as potencialidades de invocação do caráter odioso como fundamento para o repúdio, preterido em favor de outros argumentos, tais como a necessidade de alívio da dívida para a recuperação econômica. As decisões de cortes e tribunais arbitrais são igualmente oscilantes, mas com uma tendência para a cautela quando em jogo o reconhecimento das possibilidades jurídicas do repúdio. As normas de direito internacional são, assim, inconsistentes, e o recurso a princípios gerais do direito não oferece maior segurança sobre a existência, em alguma extensão, de uma permissão jurídica para o afastamento de obrigações financeiras ilegítimas. 